\title{
Monitoring and Treatment of Chronic Patients through uHealth: Keys to Sustainability (efficiency) and Quality of Care
}

Javier Cabo-Salvador ${ }^{(1-7)} /$ jcabo@telefonica.net

José Manuel Velarde(2-3) / jmvelarde@drimay.es

Verónica Cabo Muíños ${ }^{(1-5)} /$ verocabom@hotmail.com

Carlos de Castro Lozano ${ }^{(1,2,4-6)}$ / carlosdecastrolozano@gmail.com

Javier Ramos López ${ }^{(7)}$ / Javier.ramos@urjc.es

Universidad Internacional de Andalucía, España(1) / IHM-Medical Technology, Madrid-España (2) / DRIMAY Consultores, Sevilla-España(3) / Universidad a Distancia de Madrid, España(4) / Universidad Católica Nordestana, República

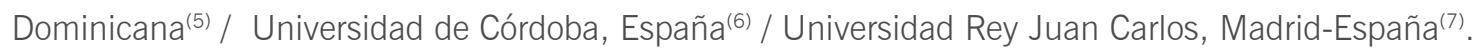

ABSTRACT This paper proposes an integrated model of social-health resources management. The authors present the actual challenges for health care, in an environment characterized by longer life expectancy and an increase in the number of patients with chronic pathologies, in a scenario of both, economic and financial crises. Their presentation includes management and financial issues, and the technological trends - such as the development of personalized and regenerative medicine- which will lead to an increase in health spending. The task of facing these challenges, they explain, cannot be postponed, the goals should be to improve: the efficiency in the use of health resources, the quality of health care and the level of patient satisfaction. Finally, they present some concepts about the application of information and communications technologies in health, show its relationship with the chronic patient care and present both, the current management models for this type of patient and the new proposed model.

KEYWORDS Sustainable Development Goals; multidimensional model; data warehouse; ontology; water. Monitorización y tratamiento de pacientes Monitoramento e tratamento de pacientes crôcrónicos mediante uHealth: claves en la sos- nicos através da uHealth: chaves para a sustentenibilidad (eficiencia) y calidad asistencial

RESUMEN Se propone un modelo integral de gestión de recursos socio-sanitarios. El artículo nicia presentando los retos que enfrenta la asistencia sanitaria en un entorno caracterizado por mayor esperanza de vida y mayor número de pacientes con patologías crónicas, en un marco de crisis económica y de financiación. La presentación incluye aspectos de gestión y financieros, así como tendencias tecnológicas - como el desarrollo de la medicina personalizada y de la regenerativa-, que suponen un incremento del gasto sanitario y establecen que es inaplazable enfrentar estos retos y que la meta es mejorar la eficiencia en el uso de los recursos sanitarios, la calidad asistencial y el grado de satisfacción de los pacientes. Posteriormente, se presentan conceptos propios de la aplicación de las tecnologías de la información y las comunicaciones en salud, se muestra su relación con la atención de pacientes crónicos y se presentan los modelos actuales para su gestión y el nuevo modelo propuesto.

PALABRAS CLAVE Longevidad; gestión de pacientes crónicos; CTT; uHealth; eficiencia; atención socio-sanitaria.

\section{tabilidade (eficiência) e qualidade assistencial}

RESUMO É proposto um modelo integral de gestão de recursos sócio-sanitários. O artigo inicia apresentando os desafios enfrentados pela assistência sanitária em um ambiente caracterizado por maior expectativa de vida e maior número de pacientes com patologias crônicas, num contexto de crise econômica e de financiamento. A apresentação inclui aspectos gerenciais e financeiros, além de tendências tecnológicas - como o desenvolvimento da medicina personalizada e regenerativa -, que implicam um aumento nos gastos em saúde e estabelecem que é urgente enfrentar esses desafios e que o objetivo é melhorar a eficiência no uso dos recursos sanitários, a qualidade assistencial e o grau de satisfação dos pacientes. Posteriormente, são apresentados conceitos da aplicação das tecnologias de informação e comunicação em saúde, sua relação com o cuidado de pacientes crônicos e ainda são apresentados os modelos atuais para a sua gestão, bem como o novo modelo proposto.

PALAVRAS-CHAVE Longevidade; gestão de pacientes crônicos, TIC; uHealth; eficiência, assistência sócio-sanitária. 


\section{Longevity and Chronicity}

Health systems can be considered direct variants of social systems, they are complex, open and interrelated systems, with determiBonants of other systems, such as the political, fiscal and educational systems (Cabo-Salvador, Cabo J, \& Iglesias, 2010; Cabo-Salvador, Bellmont, Cabo J, \& Herreros, 2010). In order to be considered as systems, according to the World Health Organization [WHO], it must: Be universal, that is, provide coverage to the entire population; have comprehensive care, both hygiene and mental health, as preventive medicine, primary care, specialized assistance in all acute and chronic diseases; be equitable in the distribution of resources; be efficient, that is, provide the best benefits and the best level of health at the lowest cost; be flexible, to be able to adapt and respond quickly to new needs; and count on the participation of citizens in its planning and management (Cabo-Salvador \& Bellmont, 2014).

It is urgent to face the current challenges of health care. Thus, the impact of the aging of the population, the need to incorporate therapeutic innovations in clinical therapy (Decreto Real Ley 16/2012, Section I) and the development of personalized medicine and regenerative medicine are going to suppose, undoubtedly, an increase in health expenditure (HSGIC, 2015; Busse, Blümel, Scheller-Kreinsen, \& Zentner, 2009; Cabo-Salvador et al., 2014; Cabo-Salvador, Bellmont, Herreros, \& Cabo J, 2014; Curtis , 2012). Therefore, reforms and new forms of management are needed to strengthen sustainability, improve efficiency and introduce new models and management tools with coordination of socio-health services (Barr, et al. 2003; Boult, Kane, Pacala, \& Wagner, 1999; Cabo-Salvador, de-Castro, Cabo, Ramos, \& López, 2017; Cabo-Salvador, Ramírez, Cabo, Ramos, \& de-Castro, 2018; Coleman, Austin, Brach, \& Wagner, 2009; Sylvia et al., 2008; Weiss, 2007; Wagner, 1998; WHO, 2002; Zwar et al., 2006).

Currently, having into account a greater longevity and life expectancy of the population, as well as an increase in the number of people over 60 years of age, the increase in chronic pathologies has meant an increase in healthcare costs in a global manner. According to United Nations prospective studies (2017), the percentage of people over 60 years of age will increase from $10 \%$ of the population in 2000 to $21 \%$ of the population in 2050 (Beaglehole et al., 2008; Bodenheimer \& Berry-Millett, 2009; Cabo-Salvador, 2017; Gilmer et al., 2006; Ma-

\section{Longevidad y cronicidad}

Los sistemas sanitarios se pueden considerar variantes directos de los sistemas sociales, son sistemas complejos, abiertos e interrelacionados, con factores determinantes de otros sistemas, como el político, el fiscal y el educativo (Cabo-Salvador, Cabo J, \& Iglesias, 2010; Cabo-Salvador, Bellmont, Cabo J, \& Herreros, 2010). Para poder considerarse como sistemas, de acuerdo con la Organización Mundial de la Salud [OMS], debe: ser universal, esto es aportar cobertura a toda la población; contar con atención integral, tanto higiene y salud mental, como medicina preventiva, asistencia primaria, asistencia especializada en todas las patologías agudas y crónicas; ser equitativo en la distribución de los recursos; ser eficiente, es decir, aportar las mejores prestaciones y el mejor nivel de salud al menor coste; ser flexible, para poder adaptarse y responder de manera rápida a las nuevas necesidades; y contar con la participación de los ciudadanos en su planificación y gestión (Cabo-Salvador \& Bellmont, 2014).

“(...) resulta inaplazable hacer frente a los retos actuales de la asistencia sanitaria. Así, el impacto del envejecimiento de la población, la necesidad de incorporar las innovaciones terapéuticas en la terapia clínica" (Real Decreto-ley 16/2012, Sección I) y el desarrollo de la medicina personalizada y de la medicina regenerativa van a suponer, sin duda, un incremento del gasto sanitario (HSCIC, 2015; Busse, Blümel, Scheller-Kreinsen, \& Zentner, 2009; Cabo-Salvador et al., 2014; Cabo-Salvador, Bellmont, Herreros, \& Cabo J, 2014; Curtis, 2012). Por eso, son necesarias reformas y nuevas formas de gestión que permitan reforzar la sostenibilidad, mejorar la eficiencia e introducir nuevos modelos y herramientas de gestión con coordinación de los servicios socio-sanitarios (Barr et al., 2003; Boult, Kane, Pacala, \& Wagner, 1999; Cabo-Salvador, de-Castro, Cabo, Ramos et al., \& López et al., 2017; Cabo-Salvador, Ramírez, Cabo, Ramos, \& de-Castro, 2018; Coleman, Austin, Brach, \& Wagner, 2009; Sylvia et al., 2008; Weiss, 2007; Wagner, 1998; WHO, 2002; Zwar et al., 2006).

Actualmente, con una mayor longevidad y esperanza de vida de la población, y un incremento del número de personas mayores de 60 años, el incremento de patologías crónicas ha supuesto un incremento de los costes sanitarios de manera global. De acuerdo con estudios prospectivos de Naciones Unidas (2017), el porcentaje de personas mayores de 60 años se incrementará del 10\% de la población en el año 2000, al 21\% de la población 
en el 2050 (Beaglehole et al., 2008; Bodenheimer \& Berry-Millett, 2009; Cabo-Salvador, 2017; Cabo-Salvador, 2017; Gilmer et al., 2006; MacAdam, 2008; WHO, 2002; ONU, 2017). De acuerdo con los últimos datos publicados y contrastados en el año 2018, el gasto sanitario como proporción del PIB alcanzó la cifra media del 9,5\% en los países de la OEGD (2017), como se aprecia en la Figura 1.

Debido al aumento de la longevidad y al incremento de la esperanza de vida, el número de personas con pluripatologías que demandan atención a su carácter de cronicidad está en continuo incremento, por lo que es una auténtica prioridad en las políticas sanitarias, debido a su alta prevalencia y a la importante repercusión económica, por la mayor utilización de los servicios sanitarios que ello implica. Se estima que la atención de los procesos crónicos supone entre el 70 \% y el 75 \% del gasto sanitario total de los países industrializados (Cabo-Salvador et al., 2010; Goodwin \& Curry, 2008; Hroscikoski et al., 2006; Ouwens, Wollersheim, Hermens, Hulscher, \& Grol, 2005; Ramsey et al., 2008; WHO, 2002). Esta atención a los pacientes crónicos implica una necesidad imperiosa de cambio de paradigma del modelo de gestión actual, desde una atención fragmentada y aislada, bien social o sanitaria, hacia una integración asistencial socio-sanitaria; rediseñando la organización y optimizando los recursos socio-sanitarios; potenciando la atención primaria; reorganizando la gestión hospitalaria, enfocándola hacia una atención de pacientes agudos; trasladando la gestión de la cronicidad al ambiente familiar y comunitario, con una integración asistencial socio-sanitaria mayor, más eficiente y de mayor calidad percibida por el usuario (Arshad, Oxley, Watts, Davenport, \& Sermin, 2000; Bengoa \& Nuño, 2008; Boult et al., 2008; Cabo-Salvador et al., 2014; Cabo-Salvador et al., 2017; Cabo-Salvador, 2017).

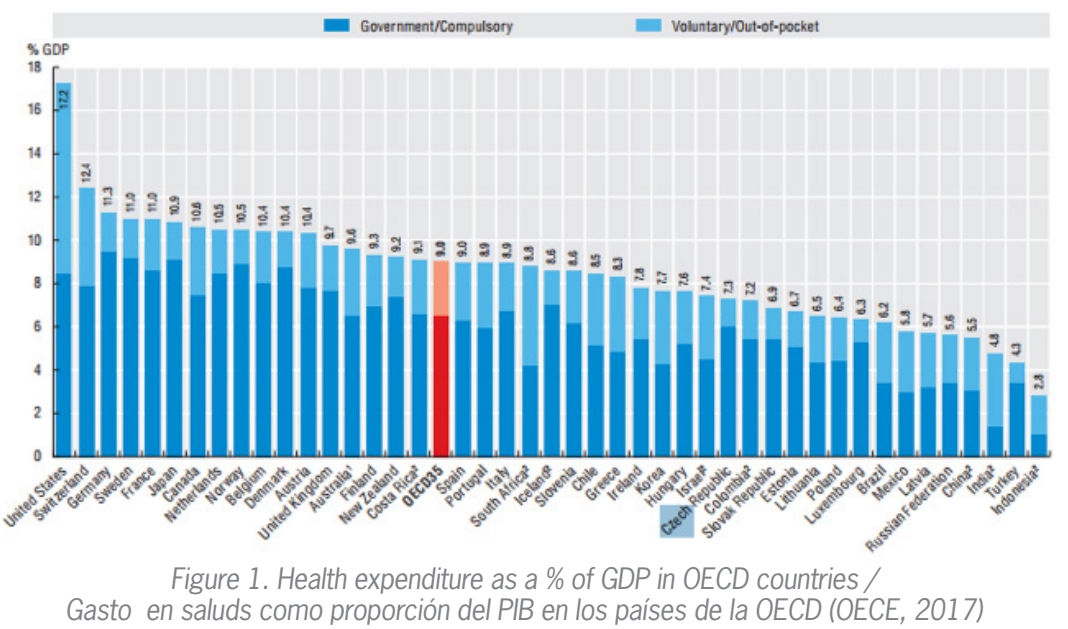

cAdam, 2008; WHO, 2002; UN, 2017). According to the latest data published and contrasted in 2018, health spending as a proportion of GDP reached the average figure of $9.5 \%$ in the OECD countries (OECD, 2017), as shown in Figure 1.

Due to the increase in longevity and life expectancy, the number of people with multiple pathologies that demand attention to their character of chronicity is continuously increasing, which is why it is a real priority in health policies, due to its high prevalence and the significant economic repercussion, and the greater use of health services that it implies. It is estimated an attention to chronic processes between $70 \%$ and $75 \%$ of total health expenditure in industrialized countries (Cabo-Salvador et al., 2010; Goodwin \& Curry, 2008; Hroscikoski et al., 2006; Ouwens, Wollersheim, Hermens, Hulscher, \& Grol, 2005; Ramsey et al., 2008; WHO, 2002). This attention to chronic patients implies an imperative need to change the paradigm of the current management model, from fragmented and isolated care, social or health care, to a socio-health care integration; redesigning the organization and optimizing socio-health resources; enhancing primary care; reorganizing hospital management, focusing on acute care; transferring the management of chronicity to the family and community environment, with a greater, more efficient and higher quality social-health care integration perceived by the user (Arshad, Oxley, Watts, Davenport, \& Sermin, 2000; Bengoa \& Nuño, 2008; Boult et al., 2008; Cabo-Salvador et al., 2014; Cabo-Salvador et al., 2017; Cabo-Salvador, 2017).

In recent years, due to the economic crisis - which entails scarcity of resources-, the increase in longevity -with an increase in patients with chronic diseases with high costs-, and the introduction of new technologies, they have been carried out in different countries, several attempts to order and prioritize health services, given that the available resources are limited and that investing more resources in one sector implies investing fewer resources in another (opportunity cost), to ensure the provision of the most important services. Today, the world health expenditure is about US $\$ 5.5$ billion per year and within that expenditure, historically the largest item corresponds to the 
hospital sector (hospital and specialized services) with approximately $54.2 \%$ of the total, followed by expenses in pharmacy with $21.5 \%$. In a global way, hospitals consume the highest percentage of the health budget and that is why the practical application of the new integrated model of socio-health resources management can not only improve efficiency but also help in sustaining health systems. Improving the efficiency and degree of use of resources in health systems (expenditure control) and improving the quality of care (morbidity and mortality reduction) and achieving a high degree of satisfaction on the part of citizens should be the main objectives of health officials from both public and private institutions (Cabo-Salvador \& Unda, 2010; Cabo-Salvador, Bellmont, Cabo J, \& Cabo V, 2014; Gravelle et al., 2007; Gonseth, Guallar-Castillón, Banegas, \& Rodríguez-Artalejo, 2004; Kane, Keckhafer, \& Robst, 2002; Kane, Keckhafer, Flood, Bershadsky, \& Siadaty, 2003; NPHS, 2006; Norris et al., 2002; WHO, 2002).

The confluence of technology-based products, platforms and applications in the health sector and solutions with intelligent cognitive systems, together with a more proactive culture of citizens, great accessibility and the ability to transmit and manage information and data structured and unstructured-, they enable and offer, from the big hospitals, the medicalized residences or the same homes at the individual and family level, great possibilities of improvement in the health care, in the prevention of diseases, in the social and health management and in the management of chronic patients, and they are directed towards a medicine of great precision, previously unmatched (Cabo-Salvador et al., 2017; Cabo-Salvador et al., 2018; Cabo-Salvador, 2017; de-Castro, Cabo- Salvador, Ramírez, \& Garcia, 2014; Epping-Jordan, Pruitt, Bengoa, \& Wagner, 2004; Evercare, n.d; Lopez, de la Torre, Herreros, \& Cabo-Salvador, 2014; Nolte \& McKee, 2008; Ramos, Soguero, Mora, Rojo, \& Cabo-Salvador, 2014; Rosen \& Ham, 2008; Sevick et al., 2007; Singh, 2005; Wolff et al., 2009).

\section{Telemedicine and uHealth}

Artificial Intelligence $[\mathrm{AI}]$, long seen as promising in the health care sector, is already a reality. The explosion of Big Data, combined with the increase in the demand for care, originated due to the increase in the number of elderly people with chronic diseases; the costs increase and the shortage of available professionals to meet that demand; and the scarcity in number and geographical
En los últimos años, debido a la crisis económica - que conlleva escasez de recursos-, al aumento de la longevidad -con incremento de pacientes con patologías crónicas con costes elevados-, y a la introducción de nuevas tecnologías, se han llevado a cabo, en diferentes países, varios intentos de ordenar y priorizar los servicios sanitarios, dado que los recursos disponibles son limitados y que invertir más recursos en un sector implica invertir menos recursos en otro (coste de oportunidad), para asegurar la provisión de los servicios más importantes. Hoy en día,, el gasto sanitario mundial es de unos US $\$ 5,5$ billones al año y dentro de ese gasto, históricamente la mayor partida corresponde al sector hospitalario (servicios hospitalarios y especializados) con aproximadamente un $54,2 \%$ del total, seguido por los gastos en farmacia con el 21,5 \%. De manera global, los hospitales consumen el porcentaje más elevado del presupuesto sanitario y es por ello por lo que la aplicación práctica del nuevo modelo integrado de gestión de recursos socio-sanitarios puede, no solo mejorar la eficiencia, sino también ayudar en el sostenimiento de los sistemas sanitarios. Mejorar la eficiencia y el grado de aprovechamiento de los recursos en los sistemas sanitarios (control del gasto) y mejorar la calidad asistencial (disminución de la morbimortalidad) y lograr un elevado grado de satisfacción por parte de los ciudadanos, deben ser los objetivos principales de los responsables sanitarios, tanto de instituciones públicas, como privadas (Cabo-Salvador \& Unda, 2010; Cabo-Salvador, Bellmont, Cabo J, \& Cabo V, 2014; Gravelle et al., 2007; Gonseth, Guallar-Castillón, Banegas, \& Rodríguez-Artalejo, 2004; Kane, Keckhafer, \& Robst, 2002; Kane, Keckhafer, Flood, Bershadsky, \& Siadaty, 2003; NPHS, 2006; Norris et al., 2002; WHO, 2002).

La confluencia de productos con base tecnológica, las plataformas y aplicaciones en el sector salud y las soluciones con sistemas inteligentes cognitivos, junto con una cultura más proactiva de la ciudadanía, una gran accesibilidad y la posibilidad de transmitir y gestionar la información y datos -estructurados y no estructurados-, posibilitan y ofrecen, desde los grandes hospitales, las residencias medicalizadas o los mismos hogares a nivel individual y familiar, grandes posibilidades de mejora en los cuidados de la salud, en la prevención de enfermedades, en la gestión socio sanitaria y en la gestión de pacientes crónicos, y se encaminan hacia una medicina de gran precisión, previamente inigualable (Cabo-Salvador et al., 2017; Cabo-Salvador et al., 2018; Cabo-Salvador, 
2017; de-Castro, Cabo-Salvador, Ramírez, \& Garcia, 2014; Epping-Jordan, Pruitt, Bengoa, \& Wagner, 2004; Evercare, n.d; Lopez, de la Torre, Herreros, \& Cabo-Salvador, 2014; Nolte \& McKee, 2008; Ramos, Soguero, Mora, Rojo, Cabo-Salvador, 2014; Rosen \& Ham, 2008; Sevick et al., 2007; Singh, 2005; Wolff et al., 2009). Telemedicina y uHealth

La Inteligencia Artificial [IA], vista durante mucho tiempo como algo prometedor en el sector de los cuidados de salud, ya es una realidad. La explosión del Big Data, combinada con el incremento de la demanda asistencial, originado en parte por el incremento del número de personas de edad avanzada con patologías crónicas; el incremento de los costes y la escasez de oferta de profesionales disponibles para atender dicha demanda; y la escasez en número y en disponibilidad geográfica de acceso para poder llegar a toda la población necesitada, han creado una demanda de servicios no cubierta por la oferta existente, que solo puede solucionar esta nueva tecnología. En los últimos años estamos viviendo un gran progreso de la IA, que ya empezó a cubrir, de manera incipiente, esta demanda real existente. Las ventajas económicas y sociales que se pueden alcanzar integrando la IA en el sector salud son indiscutibles e imparables, de hecho, están emergiendo nuevos modelos de cuidado de salud más proactivos basados en estas tecnologías (Boult, Kane, \& Brown, 2000; Cabo-Salvador et al., 2017; Cabo-Salvador et al., 2018; Cabo-Salvador, 2017; Herreros \& Cabo-Salvador, 2014; López et al., 2014; Ramos et al., 2014).

Con el desarrollo de la IA y el Big Data podemos hoy en día realizar diagnósticos médicos, mejores y de manera más rápida y precisa, y tratamientos más efectivos, y mejorar así la calidad y eficiencia de la atención sanitaria de una manera más integral, proporcionando accesos al sistema sanitario de calidad y cuidados de salud posibles, asequibles y con buenos resultados, a gran parte de la población necesitada, todo ello sin necesidad de consumo de recursos sanitarios hospitalarios (Cabo-Salvador et al., 2017; Cabo-Salvador et al., 2018; Cabo-Salvador, 2017). Aunque los cuidados en salud siguen siendo personales -y no se quiere perder nunca el contacto humano--, habrá que redefinir el rol de los diferentes profesionales en los diferentes procesos asistenciales y asegurar que estas nuevas habilidades y enseñanzas, que ya son una realidad y están formando parte de la asistencia médica cotidiana, se incorporen en las escuelas de medicina. En el campo de la IA, tanto con la llamada inteligencia computacio- availability of access to reach all the population in need, have created a demand for services not covered by the existing offer, which can only be solved by this new technology. In the last years we are experiencing a great progress of the AI, that already began to cover, in an incipient way, this existing real demand. The economic and social advantages that can be achieved by integrating AI into the health sector are indisputable and unstoppable. In fact, new, more proactive health care models based on these technologies are emerging (Boult, Kane, \& Brown, 2000; Cabo-Salvador et al., 2017; Cabo-Salvador et al., 2018; Cabo-Salvador, 2017; Herreros \& Cabo-Salvador, 2014; López et al., 2014; Ramos et al., 2014).

With the development of AI and Big Data, we can today make medical diagnoses, better and faster and more accurate, and more effective treatments, and thus improve the quality and efficiency of health care in a more comprehensive manner, providing access to the health care system of quality and affordable health care with good results, to a large part of the population in need, all without the need for hospital healthcare resources $(\mathrm{Ca}-$ bo-Salvador et al., 2017; Cabo-Salvador et al. al., 2018; Cabo-Salvador, 2017). Although health care is still personal -and we do not want to lose human contact-, we will have to redefine the role of different professionals in the different healthcare processes and ensure that these new skills and teachings, which are already a reality and are part of daily medical assistance, can be incorporated into medical schools.

In the field of AI, we are living a spectacular breakthrough from both, the computational intelligence and Environmental Intelligence [EI] or ubiquitous computing, where the medical community is pioneering the early adoption of cognitive computing technology, thanks to its great capacity for analysis and interpretation and evaluation of data, a fundamental part in the management of chronic pluripathologic patients (Cabo-Salvador et al., 2017; Cabo-Salvador et al., 2018; Cabo-Salvador, 2017; Fussell, 2006; Hébert et al., 2009; Kreindler, 2008; Morgan, Zamora, \& Hindmarsh, 2007; Oeseburg, Wynia, Middel, \& Reijneveld, 2009; Ollero, 2002; OPIMEC, 2018; Pearson et al., 2005; Russell, Thille, Hogg, \& Lemelin, 2005; Tracy, Dantas, Moineddin, \& Upshur, 2003; Vickers, Kramer, \& Baker, 2006).

The center of this revolution includes the mass production and the widespread use of technologies derived from the development of digital logic circuits that use 
binary codes [bits], such as digital computers, smartphones and tablets. The architecture of the information systems is one of the key points in the design of the Electronic Medical Record [EMR], with the purpose that they serve, not only for registration and data storage, but for purposes of clinical management considering the interrelation between the central database [Data Warehouse], under the skeleton of the conventional clinical history, nourished on the basis of the Minimum Basic Data Set [MBDS] extracted from the care process. The great technological advances, together with wireless connectivity, currently through $\mathrm{Wi}-\mathrm{Fi}$ and in the immediate future through Li-Fi [light fidelity]. All of the above integrated through mobile devices, with Android or iOS operating systems, have created a great accessibility to health care. Therefore, citizens can take proactive care of their health and get a better real information about their health status, as well as make decisions based on that information and in direct collaboration or via online with the different health providers, all aimed at personalized medicine (Cabo-Salvador et al., 2017; Cabo-Salvador et al., 2018; Cabo-Salvador, 2017; de-Castro, Cabo-Salvador, Ramírez, \& Garcia, 2014; López, de la Torre, Herreros, \& Cabo-Salvador, 2014; Ramos et al., 2014; Weiss, 2007).

The u-Health [ubiquitous telemedicine] and the Information and Communication Technologies [ICT] in health, in its different modalities of teleconsultation, remote diagnosis, telemonitoring, telecare, telesurgery, teletraining and telerehabilitation, are defined as the use of information and ICTs as support for clinical care, health education and public health at a distance.

The u-Health (FIgUrE 2) is a variant of telemedicine performed with the support of mobile devices and environmental sensors (environmental intelligence). ICTs are the engine of change in the management processes of chronic patients, usually multi-pathological (chronic patients of great complexity and comorbidity who require comprehensive management with professional care, chronic patients with high risk but less complexity, combining self-management and professional care) and the strengthening of the socio-sanitary interface in an environment such as the current one, in which there is a health model focused on the care and treatment of acute patients (Cabo-Salvador et al, 2017; Cabo-Salvador et al., 2018; Cabo-Salvador, 2017; de-Castro et al., 2014; López et al., 2014, Ramos et al., 2014). nal, como con la inteligencia ambiental o computación ubicua $[\mathrm{Ambl}]$, estamos viviendo un avance espectacular, donde la comunidad médica está siendo pionera en la adopción precoz de la tecnología de computación cognitiva, gracias a su gran capacidad de análisis e interpretación y evaluación de datos, parte fundamental en la gestión de pacientes crónicos pluripatológicos ( $\mathrm{Ca}$ bo-Salvador et al., 2017; Cabo-Salvador et al., 2018; Cabo-Salvador, 2017; Fussell, 2006; Hébert et al., 2009; Kreindler, 2008; Morgan, Zamora, \& Hindmarsh, 2007; Oeseburg, Wynia, Middel, \& Reijneveld, 2009; Ollero, 2002; OPIMEC, 2018; Pearson et al., 2005; Russell, Thille, Hogg, \& Lemelin, 2005; Tracy, Dantas, Moineddin,\& Upshur, 2003; Vickers, Kramer, \& Baker, 2006).

En el centro de esta revolución esta la producción en masa y el uso generalizado de tecnologías derivadas del desarrollo de circuitos lógicos digitales que utilizan códigos binarios [bits], como los computadores digitales, los teléfonos inteligentes [smartphones] y las tabletas [tablets], y es la arquitectura de los sistemas de información uno de los puntos clave en el diseño de la Historia Clínica Electrónica [HCE], con la finalidad de que sirvan, no solo de registro y almacenamiento de datos, sino con fines de gestión clínica con interrelación entre la base de datos central [Data Warehouse], bajo el esqueleto de la historia clínica convencional, nutrida con base en el Conjunto Mínimo Básico de Datos [CMBD] extraído del proceso asistencial. Los grandes avances tecnológicos, junto con la conectividad inalámbrica, actualmente con Wi-Fi y en un futuro inmediato mediante Li-Fi [ $l i$ ght fidelity], y todo ello integrado a través de dispositivos móviles, con sistemas operativos Android o iOS, han creado una gran accesibilidad a los cuidados de salud, de manera que los ciudadanos puede tener un cuidado proactivo de su salud y mejor y más real información acerca de su estado de salud, y tomar decisiones con base en una mayor información y en colaboración bien directa o vía on-line con los diferentes proveedores de salud, todo ello encaminado hacia una medicina personalizada (Cabo-Salvador et al., 2017; Cabo-Salvador et al., 2018; Cabo-Salvador, 2017; de-Castro, Cabo-Salvador, Ramírez, \& Garcia, 2014; Lopez, de la Torre, Herreros, \& Cabo-Salvador, 2014; Ramos, Soguero, Mora, Rojo, \& Cabo-Salvador, 2014; Weiss, 2007).

La u-Health [telemedicina ubicua] y las Tecnologías de la Información y las Comunicaciones [TIC] en sanidad, en sus diferentes modalidades de teleconsulta, tele- 
diagnóstico, telemonitarización, teleasistencia, telecirugía, teleformación y telerehabilitación, se definen como el uso de la información electrónica y las TIC como apoyo a la asistencia clínica, la educación sanitaria y la salud pública a distancia. La u-Health (Figura 2) es una variante de la telemedicina realizada con el apoyo de los dispositivos móviles y de sensores ambientales (inteligencia ambiental). Las TIC son el motor del cambio en los procesos de gestión de pacientes crónicos, generalmente pluripatológicos (pacientes crónicos de gran complejidad y comorbilidad que requieren una gestión integral con cuidados profesionales, pacientes crónicos de alto riesgo pero menor complejidad, se combinan autogestión y cuidados profesionales) y de la potenciación del interface socio-sanitario en un entorno como el actual, en el que hay un modelo sanitario enfocado al cuidado y tratamiento de enfermos agudos (Cabo-Salvador et al., 2017; Cabo-Salvador et al., 2018; Cabo-Salvador, 2017; de-Castro et al., 2014; López et al., 2014; Ramos et al., 2014).

El impacto de las TIC es decisivo en el desarrollo de la medicina y clave en la gestión de pacientes crónicos, mejora la calidad asistencial y la seguridad y cambia el concepto de equidad y accesibilidad, al salvar las barreras geográficas, políticas, económicas y administrativas, ayudando a mejorar la continuidad del proceso asistencial con base en la eficiencia, eficacia y efectividad, reduciendo costes, evitando duplicidad de pruebas, agilizando procesos, evitando el desarrollo de morbilidades y posibilitando el desarrollo de la medicina personalizada. La adopción de tecnologías de computación en la nube [cloud computing], al ofrecer servicios de computación a través de una red, generalmente Internet, ha dinamizado aún más la implantación de la telemedicina y de los Historiales Médicos Electrónicos (HME) en nuestro entorno asistencial (Cabo-Salvador et al., 2017; Cabo-Salvador et al., 2018; Cabo-Salvador, 2017; Clark Jr, Snyder, Meek, Stutz, \& Parkin, 2001; Drennan \& Goodman, 2004; MedPAC, 2007; Sheaff et al., 2009; Sylvia et al., 2006; John Hopkins University, 2010; Tinetti, Bogardus \& Agostini, 2004).

El incremento de la longevidad y el aumento de patologías crónicas implica un incremento en la demanda de servicios asistenciales, ya de por sí hoy saturados, lo que implica un incremento en la necesidad de recursos, tanto estructurales y materiales, como humanos, y una oportunidad para la telemedicina y la teleasisten-
The impact of ICT is decisive in the development of medicine and key in the management of chronic patients, since it improves the quality of care and safety. It also changes the concept of equity and accessibility, by overcoming geographical, political, economic, and administrative barriers, as well as helping to improve the continuity of the care process based on efficiency, effectiveness and effectiveness, reducing costs, avoiding duplication of tests, streamlining processes, avoiding the development of morbidities, and enabling the development of personalized medicine. By offering computer services through a network, generally Internet, the adoption of cloud computing technologies has further boosted the implementation of telemedicine and Electronic Medical Records [EMR] in our healthcare environment (Cabo-Salvador et al., 2017; Cabo-Salvador et al., 2018; Cabo-Salvador, 2017; Clark Jr., Snyder, Meek, Stutz, \& Parkin, 2001; Drennan \& Goodman, 2004; MedPAC, 2007; Sheaff et al., 2009; Sylvia et al., 2006; John Hopkins University, 2010; Tinetti, Bogardus, \& Agostini, 2004).

The increase in both longevity and chronic pathologies, implies an increase in the demand for healthcare services, which implies an increase for resources need, both structural and material, as well as human, and an opportunity for telemedicine and telecare, both for remote diagnoses (telehealth: Telecardiology, teleophthalmology, teledermatology), and for remote monitoring of assisted patients, not only in Intensive Surveillance Units [ISUs], Intensive Care Units [IGUs], Reanimation Units [RUs] and hospitals emergency boxes, but also in outpatient health and para-healthcare centers, such as pharmacies or local rural support centers; as well as medicalized residences and private homes (home health care). The above, through the development and application of vital signs detection systems, the use of nano-

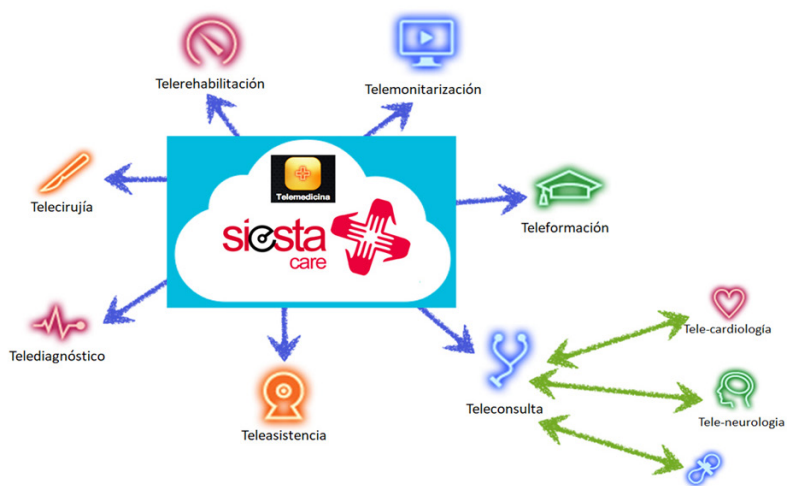

Figure 2. uHealth. Hospital with out barriers. Personalized Medicine / uHealth Hospital Sin Barreras. Medicina Personalizada 
technology and Environmental Intelligence [ET and its transmission through interactive screens, smartphones and tablets (iPad), with the development of EMR [Electronic Medical Records] for preventive diagnostic tests (Barr et al., 2003; Boult et al., 1999; Cabo-Salvador et al., 2017; Cabo-Salvador et al., 2018; Cabo-Salvador, 2017; de-Castro et al., 2014; López et al., 2014; NPHS, 2006; Nolte \& McKee, 2008; Oeseburg et al., 2009; Ovretveit \& Staines, 2007; Parchman, Zeber, Romero, \& Pugh, 2007; Parchman \& Kaissi, 2009; Shojania et al., 2006; Sperl-Hillen, 2004; Wagner et al., 2001; Wagner, Davis, Schaefer, Von-Korff, \& Austin, 1999).

Definitely, ICT, in addition to improving the quality of care, play an important role in patient safety and lead to savings in the consumption of healthcare resources (avoiding duplicities in diagnostic tests), with a reduction in medical errors, avoiding morbidities associated with inappropriate treatments and improving care through an Evidence-Based Medicine [EBM]. ICTs will play a very important role in health organizations with the aim to improve the quality, efficacy and efficiency of health services, as strategic management tools, which are keys to increase accessibility and equity. They also optimize administrative processes, through the improvement of the care continuity, the enhancement of interoperability between the different healthcare centers, giving support in Homecare and managing chronic patients. The above by improving the efficiency and sustainability of health systems and increasing the quality and safety of care, and also helping to make clinical and management decisions (Cabo-Salvador et al., 2017; Cabo-Salvador et al., 2018; Cabo-Salvador, 2017; Drennan \& Goodman, 2004; Kreindler, 2008).

ICTs are the change engine in the management processes of chronic patients, generally multi-pathological. On the other hand, they are the strengthening of the socio-health care interface, in an environment such as the current one, in which there is a health model focused on the care and treatment of acute patients. We are currently in a change of paradigm of the health model, change of the absolutely necessary assistance model that is heading for a restructuring of the assistance services concerning a management by processes, matrix, and towards a disease management, Therefore, it implies an organizational change in which coordination is essential at a social and health level. Understanding the above as an integrated model with real interoperability between cia, tanto para los diagnósticos a distancia (telehealth: telecardiología, teleoftalmología, teledermatología), como para la monitorización remota de pacientes asistidos, ya no solo en las Unidades de Vigilancia Intensiva [UVI], Unidades de Cuidados Intensivos [UCI], unidades de reanimación [REA] y boxes de Urgencias de los hospitales, sino también en centros ambulatorios sanitarios y parasanitarios, como las farmacias o los centros locales de apoyo rurales, y en las residencias medicalizadas y los domicilios particulares (asistencia sanitaria domiciliaria), mediante el desarrollo y la aplicación de sistemas de detección de signos vitales, el uso de la nanotecnología y la Inteligencia Ambiental (AmbI) y su transmisión a través de pantallas interactivas, teléfonos inteligentes y tabletas (iPad), con el desarrollo de los EMR [Electronic Medical Records] para los test de diagnóstico preventivo (Barr et al., 2003; Boult et al., 1999; Cabo-Salvador et al., 2017; Cabo-Salvador et al., 2018; Cabo-Salvador, 2017; de-Castro et al., 2014; López, 2014; NPHS, 2006; Nolte \& McKee, 2008; Oeseburg et al., 2009; Ovretveit \& Staines, 2007; Parchman, Zeber, Romero, \& Pugh, 2007; Parchman \& Kaissi, 2009; Shojania et al., 2006; Sperl-Hillen, 2004; Wagner et al., 2001; Wagner, Davis, Schaefer, Von-Korff, \& Austin, 1999).

En definitiva, las TIC, además de mejorar la calidad asistencial, juegan un papel muy importante en la seguridad del paciente y van a suponer un ahorro en el consumo de recursos sanitarios (evitando duplicidades de pruebas diagnósticas), con reducción de los errores médicos, evitando morbilidades asociadas a tratamientos no adecuados y mejorando la asistencia mediante una medicina basada en la evidencia [MBE]. Las TIC juegan y jugarán un papel muy importante en las organizaciones sanitarias para mejorar la calidad, eficacia y eficiencia de los servicios sanitarios, como herramientas de gestión estratégica, claves para incrementar la accesibilidad y la equidad y optimizar los procesos administrativos, mejorando la continuidad asistencial, potenciando la interoperabilidad entre los diferentes centros asistenciales, dando soporte en la asistencia domiciliaria (Home Care) y a la gestión de pacientes crónicos, mejorando la eficiencia y la sostenibilidad de los sistemas sanitarios e incrementando la calidad asistencial y la seguridad de la asistencia, y ayudando a la toma de decisiones clínicas y de gestión (Cabo-Salvador et al., 2017; Cabo-Salvador et al., 2018; Cabo-Salvador, 2017; Drennan \& Goodman, 2004; Kreindler, 2008). 
Las TIC son el motor del cambio en los procesos de gestión de pacientes crónicos generalmente pluripatológicos y de la potenciación de la interface de asistencia socio sanitaria, en un entorno como el actual, en el que hay un modelo sanitario enfocado al cuidado y tratamiento de enfermos agudos. Actualmente estamos en un cambio de paradigma de modelo sanitario, cambio de modelo asistencial absolutamente necesario que se encamina hacia una reestructuración de los servicios asistenciales hacia una gestión por procesos, matricial, y hacia una gestión de la enfermedad [disease management], lo que implica un cambio organizativo en el que la coordinación es esencial a nivel social y a nivel sanitario, entendiendo este como un modelo integrado con interoperabilidad real entre asistencia primaria y especializada, modelo centrado en el paciente y que potencia y fomenta su autocuidado y la corresponsabilidad a la hora de gestionar su situación de cronicidad. El potencial de la uHealth radica en la posibilidad de interactuar directamente, incluso on-line, con los profesionales del sector sanitario, lo que nos permite gestionar nuestra propia salud a través de Internet, con el soporte de las TIC, convergiendo con las tendencias tecnológicas actuales, como la $i$ Cloud, un sistema de almacenamiento tipo nube o cloud computing (Cabo-Salvador et al., 2017; Cabo-Salvador et al., 2018; Cabo-Salvador, 2017; de-Castro et al., 2014; López et al., 2014; Ramos et al., 2014).

\section{uHealth y TIC en enfermos crónicos}

La uHealth, la nanotecnología y la Inteligencia Ambiental nos permiten conocer el estado biomédico del paciente en su entorno habitual de la vida diaria y ofrecer, tanto al médico de atención primaria, como al especialista, toda la información diagnóstica de interés, permitiendo así dibujar un escenario de "Hospital sin barreras", virtualmente situado en el entorno del paciente (Home Care). En estos escenarios, el paciente está rodeado de múltiples sensores autónomos que forman redes ad hoc, ya sean BAN (Body Area Networks), PAN (Personal Area Networks) o HAN (Home Area Networks), las cuales adquieren la información de interés: desde básculas o tensiómetros portátiles, hasta monitores electrocardiogramas móviles, desfibriladores automáticos y dispositivos que pueden ser implantados en la piel o en tejidos, pasando por sensores ambientales de temperatura, humedad y posición, etc. (Cabo-Salvador et al., 2017; Cabo-Salvador et al., 2018; Cabo-Salvador, 2017; de Castro et al., 2014; López et al., 2014; Ramos et al., 2014). primary and specialized care, mainly a patient-centered model that encourages self-care and co-responsibility to manage your chronic situation. The potential of uHealth lies in the possibility of interacting directly, even online, with professionals in the health sector, which allows us to manage our own health through the Internet, with the support of ICT, converging with current technological trends, such as iCloud, a cloud computing storage system (Cabo-Salvador et al., 2017; Cabo-Salvador et al., 2018; Cabo-Salvador, 2017; de-Castro et al., 2014; López et al., 2014; Ramos et al., 2014).

\section{uHealth and ICT in Chronic Patients}

UHealth, nanotechnology and Environmental Intelligence allow us to know the patient's biomedical status in their usual environment everyday life as well as offer all the diagnostic information of interest for both, the primary care physician and the specialist. Hence, it allows us to draw a "Hospital without barriers" scenario, virtually located in the patient's environment (Home Care). In these scenarios, the patient is surrounded by multiple autonomous sensors that form ad hoc networks, such as BAN [Body Area Networks], PAN [Personal Area Networks] or HAN [Home Area Networks], which acquire the information of interest: From scales or portable tensiometers, up to mobile electrocardiogram monitors, automatic defibrillators and devices that can be implanted in the skin or tissues, through environmental temperature, humidity and position sensors, etc. (Cabo-Salvador et al., 2017; Cabo-Salvador et al., 2018; Cabo-Salvador, 2017; de Castro et al., 2014; López et al., 2014; Ramos et al., 2014).

Currently, telemedicine medical applications are mainly focused on the patient, but the role of health professionals in this environment should not be forgotten: Doctors, caregivers, pharmacies and pharmaceutical laboratories, which are often the forgotten of the system. Achieving synergy among all actors, and focusing on patients, are the main challenges faced by the current and the future telemedicine.

The Environmental Intelligence [EI] is a concept that currently arouses much interest due to a new conception of the use of computers within a habitable environment. The implementation of this technology implies a further step in the mode of interaction between the user and the machines. The emerging concept of EI offers the possibility that in everyday environment (home, moving on 
the street, in transport, in public places, in hospitals, etc.) the user can have integrated intelligence that facilitates daily life. The EI is not a prediction of the future, but a vision. EI refers to the future of the information and communications society as a consequence of the convergence of ubiquitous communication and easy-to-use interfaces (Cabo-Salvador, 2017; de Castro et al., 2014).

EI-based systems produce intuitive and intelligent interfaces, which are included in everyday objects and environments (furniture, clothing, vehicles, roads and even in paint or tissue particles), capable of detecting human presence and their needs, which respond to discontinuous, discrete and are often invisible. Ubiquity, transparency and intelligence are the three basic properties of intelligent environments: ubiquity to find them at the point where the user is; transparency to go unnoticed in the physical environment; and intelligence to get an adaptation to the preferences of each individual. Autonomous power capacity is one of the most significant aspects of the devices. Therefore, we have to find efficient methodologies, that is, materials and systems that can maximize the energy and minimize the consumption of the emission-reception units (Cabo-Salvador, 2017; de Castro et al., 2014).

In EI environments, ICT-based devices and computers "blur" at the bottom of them, while individuals are surrounded by intelligent and intuitive interfaces integrated into all types of objects. The environment recognizes individuals and some of their desires and needs, as well as the change of their own environment. EI would respond without discontinuity, discreetly and sometimes invisible, but always under human control.

There would be intelligent agents with the power of making decisions or carrying out some action (de Castro et al., 2014).

The EI offers the possibility of having integrated intelligence that facilitates process and matrix management, in all day-to-day environments. The concept of EI is a frontier terrain between the latest advances in ubiquitous computing and the new concepts of intelligent interaction between user and machine. In the real field, EI consists of the interaction of a series of everyday objects with "soft" and non-intrusive interactive qualities.

The specific benefits provided by uHealth and EI in the care processes include the best quality of care, either by having quick and easy access to specialists or because of the possibility that physicians have more informa-
Actualmente, las aplicaciones médicas de telemedicina van orientadas fundamentalmente al paciente, pero no se debe olvidar el papel que juegan los profesionales de la salud en este entorno: los médicos, los cuidadores, las farmacias y los laboratorios farmacéuticos, que con frecuencia son la parte olvidada del sistema. Lograr una sinergia entre todos los actores, centrada en los pacientes, es el principal reto al que se enfrentan la telemedicina actual y futura.

La inteligencia ambiental [Ambient Intelligence, AmbI] es un concepto que actualmente suscita mucho interés debido a una nueva concepción del uso de los ordenadores dentro de un entorno habitable. La implementación de esta tecnología implica un paso más en el modo de interacción entre el usuario y las máquinas. El concepto emergente de AmbI ofrece la posibilidad de que en todo entorno cotidiano (hogar, en movimiento por la calle, en los transportes, en los lugares públicos, en los hospitales, etc.) se pueda tener inteligencia integrada que facilite la vida diaria. La AmbI no es una predicción del futuro, sino una visión. AmbI se refiere al futuro de la sociedad de la información y las comunicaciones como consecuencia de la convergencia de la comunicación ubicua y de las interfaces fáciles de usar (Cabo-Salvador, 2017; de Castro et al., 2014).

Los sistemas basados en AmbI producen interfaces intuitivas e inteligentes, que son incluidas en objetos y entornos cotidianos (muebles, ropa, vehículos, carreteras e incluso en partículas de pintura o tejidos), capaces de detectar la presencia humana y sus necesidades, que responden de manera discontinua, discreta y son, con frecuencia, invisibles. Ubicuidad, transparencia e inteligencia son las tres propiedades básicas de los ambientes inteligentes: ubicuidad para encontrarlos en el punto donde esté el usuario; transparencia para pasar desapercibidos en el medio físico; e inteligencia para adaptarse a las preferencias de cada individuo. La capacidad de alimentación autónoma es uno de los aspectos más significativos de los dispositivos. Por esto, tenemos que encontrar metodologías eficientes, es decir, materiales y sistemas que puedan aprovechar al máximo la energía y reducir al mínimo el consumo de las unidades de emisión-recepción (Cabo-Salvador, 2017; de Castro et al., 2014).

En los entornos de inteligencia ambiental, los dispositivos basados en TIC y los ordenadores se "difuminan" en el fondo de ellos, mientras que los individuos se encuentran rodeados de interfaces inteligentes e intuitivas 
integradas en todo tipo de objetos. El entorno reconoce a los individuos y algunos de sus deseos y necesidades, así como el cambio del propio entorno. AmbI respondería, como se dijo, sin discontinuidad, de manera discreta y a veces invisible, pero siempre bajo el control humano. Habría agentes inteligentes con la función de tomar decisiones o llevar a cabo alguna acción (de Castro et al., 2014).

La AmbI ofrece la posibilidad de tener inteligencia integrada que facilite la gestión por procesos y la gestión matricial, que en todos los entornos cotidianos. El concepto de AmbI es un terreno fronterizo entre los últimos avances en computación ubicua y los nuevos conceptos de interacción inteligente entre usuario y máquina. En el terreno práctico, la AmbI consiste en la interacción de una serie de objetos de uso cotidiano con cualidades interactivas "suaves" y no intrusivas.

Entre los beneficios específicos que aportan la uHealth y la AmbI en los procesos asistenciales está la mejor calidad asistencial, bien por tener acceso de forma sencilla y rápida a especialistas o bien por la posibilidad de que los facultativos dispongan de mayor cantidad de información acerca del paciente. Además, los pacientes evitarán gastos derivados del "coste de viaje" y pérdida de tiempo y evitaran la inconveniencia de recorrer, en ocasiones, largas distancias para realizar consultas adicionales cuando se requiere contar con la opinión de un especialista. La uHealth ofrece la posibilidad de recabar, independientemente de la ubicación geográfica, una segunda opinión para la realización de diagnósticos, una mejora de la coordinación clínica y terapéutica y la posibilidad de apoyo a los médicos que ejercen su labor en zonas aisladas. La uHealth favorece la equidad y la universalidad del servicio sanitario, mejorando la continuidad asistencial, permitiendo el suministro de asistencia sanitaria de calidad en las zonas remotas del país y facilitando una menor duración de la estancia en el hospital, lo que se traduce en una mejor utilización de los recursos y una mayor rapidez en la incorporación del paciente a su medio habitual, reduciendo las necesidades de desplazamientos y transporte que deben ser asumidos por el sistema sanitario (Cabo-Salvador et al., 2018; Cabo-Salvador, 2017).

Mediante la utilización de la uHealth se puede conseguir una interoperabilidad eficaz de manera que cada entorno asistencial (atención primaria y atención especializada) disponga de la información suficiente y tenga capacidad para intercambiar la información de una manera segura, rápida, eficiente y de calidad. tion about the patient. In addition, patients will avoid expenses derived from the "travel cost" and loss of time. They will avoid the inconvenience of traveling, sometimes, long distances to perform additional consultations required to have the opinion of a specialist. The uHealth offers the possibility of collecting, independently of the geographical location, a second opinion for the generation of diagnoses, an improvement of the clinical and therapeutic coordination, and the possibility of support to the doctors who work in isolated areas. The uHealth helps the equity and universality of the health service, improving the continuity of care, allowing the provision of quality health care in the remote areas of the country, and facilitating a shorter length stay in the hospital. The above means a better use of resources and greater speed in incorporating the patient into their usual environment, reducing the need for travel and transportation that should be assumed by the health system (Cabo-Salvador et al., 2018; Cabo-Salvador, 2017).

The use of uHealth allows to achieve an effective interoperability. Thus, each assistance environment (primary care and specialized care) has sufficient information and has the capacity to exchange information in a safe, fast, efficient, and quality way.

As mentioned, we are witnessing a worldwide demographic change. The inhabitants of the most developed countries live longer. Hence, the population is aging at an appreciable rate. Some of the pathologies that are considered chronic nowadays, in addition to others that clinical advances will become chronic, will be a true pandemic worldwide, and the cost of their treatment will be unaffordable, unless the way in which patients interact with the health system is changed. As an example, the new technologies will have a fundamental role in the life of the elderly with cognitive deficiencies or mental disorders. These technologies can also be used to stimulate the intellectual activity of the elderly, with the aim to slow down the cognitive deterioration, as far as possible.

Through ICT, innovative diagnostic and predictive methods are developed around centralized databases with information from multiple patients with clinical, analytical (biochemical and anatomopathological) data, as well as molecular and genetic profiles. Therefore, these data can be integrated with applications that allow presenting, transmitting, and extracting information in the form of individualized and modeled phenotypes with the development of AI algorithms. It allows the de- 
sign of individualized and optimal treatments according to the type of pathology, which will serve as support tools for the pathology identification, the biological characteristics knowledge, the severity and aggressiveness degrees of the lesion, and the possible resistance to therapies and drugs. As a result, the application of aggressive and expensive non-effective treatments is avoided and it is possible to choose the most appropriate treatment, according to the patient's personal and clinical profile (personalized medicine). Consequently, they will improve their survival and quality of life, cost-utility result of the procedures or therapies and the QALY ratio [Quality-Adjusted Life Year] in the procedures used.

Certainly, ICTs will lead to savings in the consumption of healthcare resources through the reduction of medical errors, the possibility of avoiding morbidities associated with inappropriate treatments and the best assistance to the patient through evidence-based medicine. ICT will change the doctor-patient relationship with an increase in consultations through the web environment and videoconferences, and through the physical support of robotics using "MD robots", with remote-controlled mobility and assisted by cameras with audiovisual and reception capabilities, as well as the delivery, the data and images reproduction in real time, and the on-line diagnosis and prescription.

The potential of home-based technologies based on multiple sensors that collect patient data (smart homes) is highlighted. The ICT will play a very important role in the efficiency and control of expenses by avoiding tests duplication, improving the continuity of care, promoting interoperability between the different centers and giving support in home care and chronic management. ICT enhance the development of support systems in decision-making, improve care equity, and rationalize and control pharmaceutical expenditure through electronic prescription. They also facilitate access to diagnostic and therapeutic technologies, guaranteeing their rational use (EBM), and improving assistance, teaching, research, health planning, and public health control through the EMR (Cabo-Salvador et al., 2017; Cabo-Salvador et al., 2018; Cabo-Salvador, 2017).

There is a great expectation and a market of more than 10 billion dollars in 2018 and a large field of action for professionals with different possible programming strategies such as the responsive design trend, based on the development of Web pages with HTML5 technolo-
Como se mencionó, estamos asistiendo a un cambio demográfico a nivel mundial. Los habitantes de los países más desarrollados viven más tiempo y, por tanto, la población está envejeciendo a un ritmo apreciable. Algunas de las patologías que se consideran crónicas en la actualidad, además de otras que los avances clínicos convertirán en crónicas, serán una auténtica pandemia a nivel mundial y el coste de su tratamiento será inasumible, a no ser que se cambie la forma en la que los pacientes interactúan con el sistema de salud. A modo de ejemplo, las nuevas tecnologías habrán de tomar un papel fundamental en la vida de los ancianos con deficiencias cognitivas o desórdenes mentales, estas tecnologías podrán utilizarse además para estimular la actividad intelectual de las personas mayores, de forma que se ralentice el deterioro cognitivo, en la medida de lo posible.

Por medio de las TIC se desarrollan innovadores métodos diagnósticos y predictivos, en torno a bases de datos centralizadas con información de múltiples pacientes con datos clínicos, analíticos (bioquímicos y anatomopatológicos) imágenes y perfiles moleculares y genéticos. A través de ellas, se pueden integrar dichos datos con aplicaciones que permitan presentar, transmitir y extraer información en forma de fenotipos individualizados y modelados con el desarrollo de algoritmos de IA. Esto permite el diseño de tratamientos individualizados, óptimos según el tipo de patología, que servirán como herramientas de apoyo para la identificación de la patología y el conocimiento de las características biológicas y los grados de severidad y agresividad de la lesión, y la posible resistencia a terapias y fármacos. De esta manera, se evita la aplicación de tratamientos agresivos y caros no efectivos y se hace posible elegir el tratamiento más adecuado, de acuerdo con el perfil personal y clínico del paciente (medicina personalizada), mejorando así su supervivencia y calidad de vida, el resultado coste-utilidad de los procedimientos o terapias y el ratio AVAC [Años de Vida Ajustados a la Calidad] en los procedimientos empleados.

En definitiva, las tecnologías de la información ylas comunicaciones van a suponer un ahorro en el consumo de recursos sanitarios mediante la reducción de errores médicos, la posibilidad de evitar morbilidades asociadas a tratamientos no adecuados y la mejor asistencia al paciente mediante medicina basada en la evidencia. Las TIC cambiarán la relación médico-paciente con un incremento de las consultas a través del entorno web y las videoconferencias, y mediante el apoyo físico de la robótica me- 
diante "robots MD", con movilidad teledirigida y asistida por cámaras con pantallas con capacidad audiovisual y de recepción, envío y reproducción de datos e imágenes en tiempo real, y diagnóstico y prescripción on-line.

Se destaca el potencial de las tecnologías en el hogar basadas en múltiples sensores que recogen datos del paciente (smart homes). Las TIC jugarán un papel muy importante en la eficiencia y control del gasto evitando duplicidad de pruebas, mejorando la continuidad asistencial, potenciando la interoperabilidad entre los diferentes centros y dando soporte en la asistencia domiciliaria y la gestión de crónicos. Las TIC potencian el desarrollo de sistemas de apoyo en la toma de decisiones, mejoran la equidad asistencial, racionalizan y controlan el gasto farmacéutico mediante la receta electrónica, facilitan el acceso a tecnologías diagnósticas y terapéuticas, garantizando su uso racional (MBE), y mejoran la asistencia, docencia, investigación, planificación sanitaria y control de la salud pública mediante la HCE (Cabo-Salvador et al., 2017; Cabo-Salvador et al., 2018; Cabo-Salvador, 2017).

Existe una gran expectativa y un mercado de más de 10 billones de dólares en 2018 y un gran campo de actuación para los profesionales con diferentes estrategias posibles de programación como la tendencia responsive design, basada en el desarrollo de páginas Web con tecnología HTML5, que es la imaginación llevada a la implementación. HTML5 es la piedra angular de la plataforma web abierta del W3C, una infraestructura diseñada para apoyar la innovación y fomentar al máximo el potencial que puede ofrecer la Web (Cabo-Salvador et al., 2018).

Actualmente, como se mencionó, estamos en un cambio de paradigma de modelo sanitario. Este modelo centrado en el paciente, potencia y fomenta su autocuidado y corresponsabilidad a la hora de gestionar su situación de cronicidad. Para este cambio de modelo sanitario es necesario: invertir en TIC; educar a los pacientes en la gestión de su enfermedad; promover la medicina basada en la evidencia; integrar los cuidados de atención primaria, atención especializada y servicios sociales; y cambiar el modelo de gestión orientado a la coordinación entre los ámbitos sociales y sanitarios asistenciales, caso donde la telemedicina y la teleasistencia pueden mejorar la calidad asistencial.

Modelos de gestión de pacientes crónicos

El manejo (gestión de procesos) y el tratamiento integral (atención socio sanitaria) de los pacientes con enferme- gy, which is the imagination taken to the implementation. HTML5 is the cornerstone of the W3C's open web platform, an infrastructure designed to support innovation and maximize the potential that the Web can offer (Cabo-Salvador et al., 2018).

Currently, as mentioned, we are in a paradigm shift in the health model. This model focused on the patient, empowers and encourages self-care and co-responsibility when it comes to managing their chronic situation. For this change of sanitary model, it is necessary: Invest in ICT; educate patients in the management of their disease; promote evidence-based medicine; integrate primary care, specialized care and social services; and change the management model oriented to coordination between the social and health care areas, where telemedicine and telecare can improve the quality of care.

\section{Chronic Patient Management Models}

The management (process management) and the integral treatment (socio-health care) of patients with chronic diseases are part of the main current challenges for the health systems of any country. The advance in the management of chronic diseases and in the management of patients with multiple pathologies (patients with two or more chronic pathologies), requires a paradigm shift of our usual concepts of acute patients' management within healthcare systems and the integral transformation of current conceptual frameworks, where citizens, their environment and their social and health needs are the real center of the health system.

The existing models of patients' management with chronic diseases that require hybrid processes and care, not only health, but also social (socio-health processes) are few and very young in their approach. All of them are derived from the Chronic Care Management [CGM], developed by Ed Wagner and collaborators in 1992 at the MacColl Institute for Healthcare Innovation in Seattle (WA), to improve the management of chronic diseases within the systems of integrated providers, such as the North American Group Health Cooperative and Lovelace Health System (Wagner, Austin, \& Von-Korff, 1996; Wagner, 1998).

This model of care has as its crucial purpose to locate patients, actively and well informed, as a central element of a system that has a dynamic team of professionals with the necessary knowledge and experience (FIGURE 3). In addition, it recognizes that the Management of chronic 
diseases is the result of the interactions of three overlapping areas: The community or country as a group, with its health policies, its health model and its multiple public and private resources; the health system, with its funding and provider organizations, and the public and private insurance systems; and the clinical practice with primary and specialized healthcare, identifying those essential interdependent elements that must interact not only effectively and effectively, but also efficiently, in order to achieve optimal care for patients with chronic diseases.

This model was the first widely disseminated system. It helped as the basis for all subsequent models, such as the Extended Chronic Care Model [ECGM], used and proposed by the Government of British Columbia (Canada), which emphasizes the importance and relevance of the community context, as well as the importance of prevention and health promotion (FIGURE 4), and creates the Innovative Care for Chronic Conditions [ICCG] framework of the World Health Organization [WHO].

Basically, all these models are only variants of Wagner's original model, which emphasize, on the one hand, the great importance and the urgent need for commitment in the project, not only on the health side, but also on the social part, an integrated form (key to this project). On the other hand, it proclaims the need to promote, at the political and cultural levels, the promotion of health and the prevention of diseases, together with the aim to optimize the use of existing resources, carrying out integral management effectively, effectively and efficiently, through the formulation of integrated socio-sanitary policies (FIGURE 5).

This innovative care of the WHO makes several key complementary contributions to the CGM and highlights the need for a unitary and strong health and social policy that can redirect the social health services, and orient them towards the real needs of patients with chronic pathologies, which is a key element of the model with a strong leadership and with collaboration, both interterritorial, as intersectoral. Hence, It provides a real integration of policies, financial sustainability, and trained and qualified human resources.

Patients with multiple chronic diseases (multi-pathological patients), with prolonged needs - not only health, but also social-, with some functional deficit that prevents them from carrying out normal and adequate daily activities - people totally dependent-, are those who consume the greater volume of health resources in a country. For this reason, the creation of new management dades crónicas son parte de los principales retos actuales para los sistemas sanitarios de cualquier país. El avance en la gestión de las enfermedades crónicas y en la gestión de los pacientes pluripatológicos (pacientes con dos o más patologías crónicas), precisa de un cambio de paradigma de nuestros conceptos habituales de gestión de pacientes agudos dentro de los sistemas sanitarios y de la transformación integral de los marcos conceptuales actuales, donde los ciudadanos, su entorno y sus necesidades socio sanitarias sean el centro real del sistema sanitario.

Los modelos existentes de gestión de pacientes con enfermedades crónicas que requieren de procesos y cuidados híbridos, no solo sanitarios, sino también sociales (procesos socio sanitarios) son pocos y muy jóvenes en su planteamiento. Todos ellos se derivan del Modelo de Cuidado Crónico [Chronic Care Management, CGM], desarrollado por Ed Wagner y colaboradores en 1992 en el MacColl Institute for Healthcare Innovation de Seattle (WA), para mejorar la gestión de enfermedades crónicas dentro de los sistemas de proveedores integrados, como el Group Health Cooperative and Lovelace Health System norteamericano (Wagner, Austin, \& Von-Korff, 1996; Wagner, 1998).

Este modelo de cuidado tiene como propósito último ubicar a los pacientes, de manera activa y bien informados, como elemento central de un sistema que cuenta con un equipo dinámico de profesionales con los conocimientos y la experiencia precisos (FIGURA 3), y reconoce que la gestión de enfermedades crónicas es el resultado de las interacciones de tres áreas superpuestas: la comunidad o país como grupo, con sus políticas sanitarias, su modelo sanitario y sus múltiples recursos públicos y privados; el sistema sanitario, con sus organizaciones financiadoras y proveedoras y los sistemas de seguros públicos y privados; y la práctica clínica o asistencia sanitaria, primaria y especializada, identificando aquellos elementos esenciales interdependientes que deben interactuar de manera no solo eficaz y efectiva, sino también de manera eficiente, para alcanzar un cuidado óptimo de aquellos pacientes con enfermedades crónicas.

Este modelo fue el primer sistema ampliamente divulgado y sirvió de base para todos los modelos posteriores, tales como el Modelo de Cuidado Crónico Extendido [Extended Chronical Care Model, ECCM], empleado y planteado por el Gobierno de la Columbia Británica (Canadá), que recalca la importancia y relevancia del contexto comunitario, al igual que la importancia de la preven- 


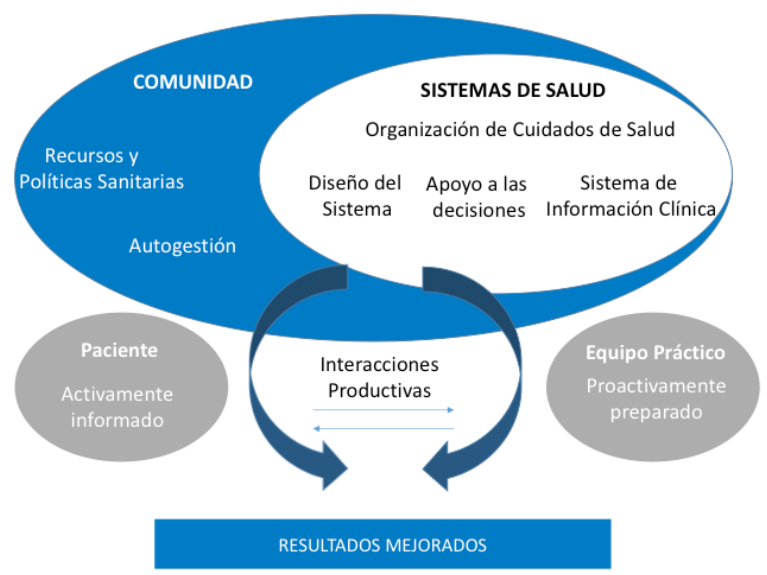

Figure 3. Chronic Care Model / Modelo de Cuidados Crónicos (MacColl Institute for Health Care Innovation, 2013)

ción y promoción sanitaria (Figura 4), y crea el Marco del Cuidado Innovador para Enfermedades Crónicas [Innovative Care for Chronic Conditions, ICCG], de la Organización Mundial de la Salud (OMS).

En el fondo, todos estos modelos son solo variantes del modelo original de Wagner, que recalcan, por un lado la gran importancia y la urgente necesidad del compromiso en el proyecto, de la parte no solo sanitaria, sino también de la parte social, de una forma integrada (clave para este proyecto), y por otro, la necesidad de potenciar, a los niveles político y cultural, la promoción de la salud y la prevención de las enfermedades, junto con la necesidad de optimizar el uso de los recursos existentes, realizando una gestión integral con eficacia, efectividad y eficiencia, mediante la formulación de políticas socio-sanitarias integradas (FIGURA 5).

Este cuidado innovador de la OMS realiza varias contribuciones claves complementarias al CCM y resalta la necesidad de una política socio sanitaria unitaria y fuerte que pueda reconducir los servicios socio sanitarios y orientarlos hacia las necesidades reales de los pacientes con patologías crónicas, un elemento primario clave del modelo con una dirección fuerte y con colaboración, tanto interterritorial, como intersectorial, que le aporta una integración real de políticas, sostenibilidad financiera y recursos humanos preparados y cualificados.

Los pacientes con múltiples patologías crónicas (pacientes pluripatológicos), con necesidades prolongadas -no solo sanitarias, sino también sociales-, con algún déficit funcional que les impida realizar de manera normal y adecuada las actividades cotidianas - personas totalmente dependientes-, son quienes consumen models valid for their management remains a national challenge. The organization of health care and health care partner, aimed at the management and treatment of these multi-pathological patients is currently improving, but it is necessary to promote and encourage the work of multidisciplinary teams (health professionals and social service professionals acting simultaneously in a synergistic and coordinated way). In this way, comprehensive and equitable health care can be guaranteed, offering: The continuity of long-term care together with an improvement in the quality of care; a more rational use of resources, both human, structural and financial employees (efficiency); and the improvement of the patients' life quality and their family environment.

In order to achieve this purpose, a classification is initially required to carry out the first step: Definition of the people identification criteria who are susceptible to inclusion in the need for integrated health care.

A stratification based on the description of the Kaiser Permanente Pyramid (Figure 6) could facilitate the clas-

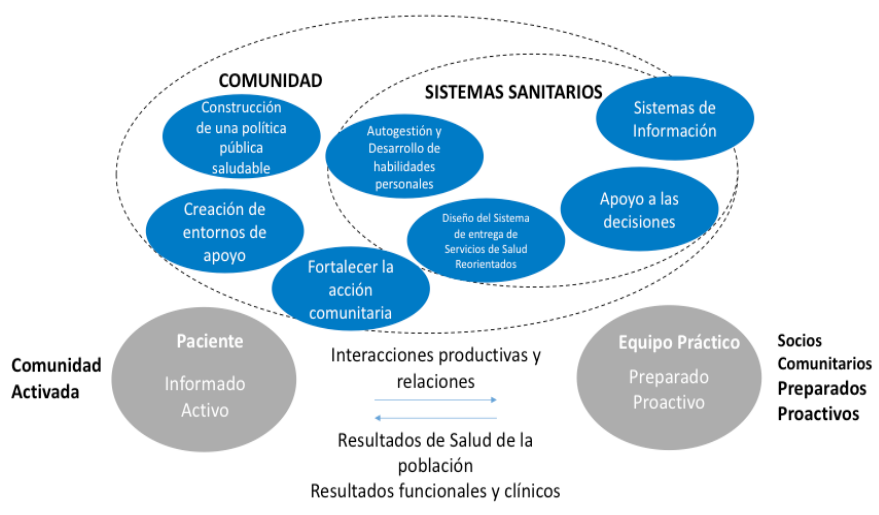

Figure 4. Expanded Chronic Care Model / Modelo de Cuidado Crónico Extendido (Barr, et al., 2003, p. 77)

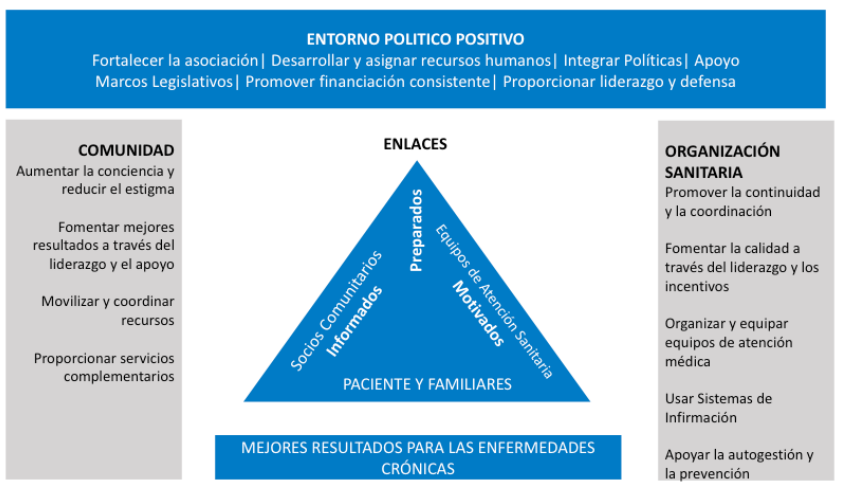

Figure 5. Innovative care for chronic conditions framework / Marco de cuidado innovador para afecciones crónicas (WHO, 2002) 
sification of these patients in three levels of intervention, according to their level of complexity. The group of patients that is located in the upper part of the pyramid, although they represent only between $3 \%$ and $5 \%$ of the cases, are the most complex and those that consume the highest portion of the health and social resources. Therefore, it is necessary to assign comprehensive care plans designed ad hoc to reduce the unnecessary use of specialized resources and, mainly, to avoid hospital admissions (Cabo-Salvador et al., 2017; Cabo-Salvador et al., 2018; Cabo-Salvador, 2017).

This risk stratification was developed in the United States of America to classify patients depending on their level of complexity and the probability that their health deteriorates. It locates at a zero level the healthy members of the population for whom the priorities are prevention and early diagnosis of the disease. In the first level is located people who have some kind of chronic disease and who do not have dependence degrees. They represent between $70-80 \%$ of chronic patients. Their interest is practically oriented to self-care, appropriate administration of medications and education in health aspects. Their social and health support needs are low. In the second level, high-risk chronic patients are located, which represent $15 \%$ of chronic patients and require a more direct management of the disease and greater socio-sanitary support. At the third level are located patients identified as complex, to whom guided care plans are assigned, called "case management projects", designed to reduce the inappropriate use of specialist services and avoid hospital admissions (Cabo-Salvador et al., 2017; Cabo-Salvador et al., 2018; Cabo-Salvador, 2017).

This Kaiser Permanente model has inspired additional approaches, such as the Guided Care Model, where primary care nursing staff, previously trained and

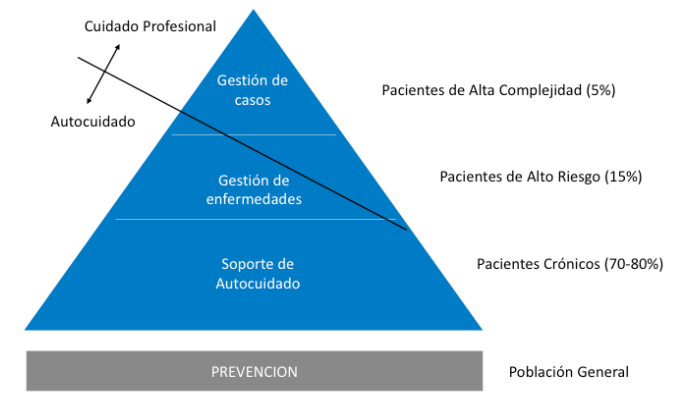

Figure 6. Kaiser Permanente pyramid of risk stratification / Pirámide de estratificación de riesgos de Kaiser Permanente (Goodwin \& Curry, 2008) el mayor volumen de los recursos sanitarios de un país. Por ello, la creación de nuevos modelos de gestión válidos para su manejo sigue siendo un reto a nivel nacional. La organización de la atención sanitaria y socio sanitaria, encaminada hacia la gestión, el manejo y el tratamiento de estos pacientes pluripatológicos es actualmente mejorable, pero es necesario potenciar y fomentar el trabajo de equipos multidisciplinares (profesionales sanitarios y profesionales de los servicios sociales actuando simultáneamente y de manera sinérgica y coordinada). De esta manera, se puede llegar a garantizar una atención socio sanitaria integral y equitativa, que ofrezca: la continuidad de los cuidados a largo plazo junto con una mejora de la calidad asistencial; un uso más racional de los recursos, tanto humanos, como estructurales y financieros empleados (eficiencia); y la mejora de la calidad de vida de los pacientes y de su entorno familiar.

Para lograr este propósito se requiere inicialmente de una clasificación para realizar el primer paso: definir los criterios de identificación de las personas que son susceptibles de inclusión en la necesidad de cuidados socio sanitarios integrados.

Una estratificación basada en la descripción de la Pirámide de Kaiser Permanente (FIGURA 6) podría facilitar la clasificación de dichos pacientes en tres niveles de intervención, de acuerdo con su nivel de complejidad. El conjunto de pacientes que se sitúa en la parte superior de la pirámide, aunque representan sólo entre el 3\% y el 5\% de los casos, son los más complejos y los que consumen la porción más elevada de los recursos socio sanitarios, por lo que es necesario asignarle planes de cuidados integrales diseñados ad hoc, para reducir de esa manera el uso innecesario de recursos especializados y, en especial, para evitar ingresos hospitalarios (Cabo-Salvador et al., 2017; Cabo-Salvador et al., 2018; Cabo-Salvador, 2017).

Esta estratificación de riesgos fue desarrollada en los Estados Unidos de América para clasificar a los pacientes dependiendo de su nivel de complejidad y de la probabilidad de que su salud se deteriore. Ubica en un nivel cero a los miembros sanos de la población para quienes las prioridades son la prevención y el diagnóstico temprano de la enfermedad. En el primer nivel se ubica a las personas que tienen algún tipo de enfermedad crónica y que no tienen grados de dependencia, representan entre el 70-80\% de los pacientes crónicos y, en su caso, el interés se orienta prácticamente al autocuidado, la administración apropiada de medicamentos y la edu- 
cación en aspectos sanitarios; sus necesidades de apoyo socio sanitario son bajas. En el segundo nivel se sitúan los pacientes crónicos de alto riesgo, representan el 15\% de los pacientes crónicos y precisan de una gestión más directa de la enfermedad y de mayor apoyo socio sanitario. En el tercer nivel se ubican los pacientes identificados como complejos a quienes se les asignan planes de cuidado guiados denominados "proyectos de gestión de caso", diseñados para reducir el uso inadecuado de servicios especialistas y evitar los ingresos hospitalarios (Cabo-Salvador et al., 2017; Cabo-Salvador et al., 2018; Cabo-Salvador, 2017).

Este modelo de Kaiser Permanente ha inspirado enfoques adicionales, como el Modelo de Cuidado Guiado, donde personal de enfermería de cuidados primarios, previamente entrenado y cualificado y en coordinación con un equipo médico, se ocupa de la valoración, evaluación, planificación, cuidado, seguimiento y supervisión de los pacientes crónicos complejos identificados por medio de modelos de predicción previamente realizados.

Independientemente de cuál sea el modelo elegido, lo que sí está claro es que se necesitan modelos específicamente diseñados para mejorar la gestión de las enfermedades crónicas y de los pacientes pluripatológicos, ya que no existen pautas clínicas prácticas que aborden las afecciones múltiples. Se necesitan nuevos modelos diseñados para permitir a los profesionales de la asistencia - primaria y especializada-, considerar las circunstancias individuales y las preferencias de los pacientes con enfermedades crónicas múltiples para poder realizar una integración multidisciplinar con profesionales del entorno sanitario y del entorno de los cuidados sociales.

Además del modelo de gestión, es necesario crear estándares de calidad para los servicios socio sanitarios destinados a estos pacientes con patologías crónicas múltiples, particularmente en relación con la coordinación del cuidado, la educación de pacientes y cuidadores, y la capacitación en el apoyo al autocuidado, considerando las preferencias y circunstancias individuales e incorporando herramientas de mejora de los procesos socio sanitarios con la ayuda de nuevas herramientas tecnológicas, como la mHealth y uHealth, la nanotecnología y la AmbI, así como a través del desarrollo de servicios más allá de los límites del sistema sanitario actual. Para ello, se necesitan sistemas de Información que aporten datos, tanto del paciente, como de los aspectos sanitarios, que se pueden obtener directamente de la explotación qualified and in coordination with a medical team, deals with assessment, evaluation, planning, care, follow-up and supervision of complex chronic patients identified through prediction models previously performed.

Regardless of which model is chosen, it is required models specifically designed to improve the management of chronic diseases and patients with multiple pathologies, since there are no practical clinical guidelines that address multiple conditions. Additionally, it is required new models designed to allow care professionals -primary and specialized- to consider the individual circumstances and preferences of patients with multiple chronic diseases with the purpose to carry out a multidisciplinary integration with professionals of the healthcare environment and the social care environment.

In addition to the management model, it is necessary to create quality standards for social health services for these patients with multiple chronic pathologies, particularly in relation to the care coordination, the education of patients and caregivers, and training in support for self-care, considering individual preferences and circumstances, and incorporating tools to improve social healthcare processes with the help of new technological tools, such as mHealth and uHealth, nanotechnology and EI, as well as the development of services beyond the limits of the current health system. Thus, there are required information systems that provide data, both from the patient and from the health aspects, that can be obtained directly from the exploitation of the Minimum Basic Data Set [MBDS], as well as additional information on social and socioeconomic aspects, which makes decision-making easier for managers (Cabo-Salvador et al., 2017; Cabo-Salvador et al., 2018; Cabo-Salvador, 2017).

\section{New Integral Model of Socio-Health Resources Management}

Our new model consists, first of all, of a social and health information system [Sistema de Información Socio Sanitario, SHIS] that will allow: The assessment of the inclusion criteria to the different offers of the social health services portfolio, and share a social and health integrated record [Historia Socio Sanitaria Integrada, HSSI], the obtaining of a MBDS specific for health and social issues [MBDSHS] and the obtaining of risk adjustment systems that allow us to know the cost of socio-health processes. Hence, it will be possible to make an efficiency and quality 
benchmarking, as well as assign resources based on the costs obtained in the different processes of the health and social services portfolio, something impossible with current information systems.

An HSSI will allow the managers to:

- Register patients and assign them an identification code;

- facilitate the follow-up of the social health process with an ABQ [Activity Based Quality] methodology focused on the quality of care, knowing how the healthcare-based healthcare processes are carried out [Activity Based Management, ABM] and what is the cost of each process [Activity Based Costing, $\mathrm{ABC}]$, all of the above as the axis of the patient process with social and health needs that has been defined as a person susceptible to inclusion;

- be able to track through a scorecard of the entire process; and

- carry out an evaluation and benchmarking with the health and social information that is available in an HSSI, interoperable and accessible, both from the social area and from the health area.

In addition to the SISS, the HSSI and the MBDS-HS, a system of risk adjustment will be required through an Aggregate Set of Social Attention [Conjunto Agregado de Atención Social, CAAS] that allows to know the cost of social processes, in order to make benchmarking of efficiency and quality and consequently allocate resources according to the costs obtained in the different processes of the social services catalog.

For that, it is necessary to carry out some Integrated Social Care Guidelines [Guías Integradas de Atención Social, GIAS] in order to standardize the processes, and a new Model of Cost Assignment to the Social Care Processes [Modelo de Asignación de Costes a los Procesos de Atención Social, $\mathrm{MacPAC}]$, in order to define a Tool for the Evaluation of Results in Social Care [Herramienta para la Evaluación de Resultados en Atención Social, HERAS].

A diagnosis of the social needs, the objectives of coverage, the strategic lines and the suitable actions for its achievement, and a forecast of its evolution are the basis of the planning. The mechanisms of systematic and continuous evaluation are the guarantee of execution with quality. These tools provide transparency in the service agreements between the companies, the suppliers, and the financial administration. del Conjunto Mínimo Básico de Datos [CMBD], como información adicional de los aspectos sociales y socioeconómicos más relevantes, que le facilite a los gestores la toma de decisiones (Cabo-Salvador et al., 2017; Cabo-Salvador et al., 2018; Cabo-Salvador, 2017).

Nuevo modelo integral de gestión de recursos socio-sanitarios

Nuestro nuevo modelo consta, en primer lugar, de un Sistema de Información Socio Sanitario [SISS] que va a permitir: la valoración de los criterios de inclusión a las diferentes ofertas de la cartera de servicios socio sanitarios que exista, y crear y poder compartir una Historia Socio Sanitaria Integrada [HSSI], la obtención de un CMBD específico socio sanitario [CMBDSS] y a la obtención de sistemas de ajuste de riesgos que permitan conocer el coste de los procesos socio sanitarios. De esta manera, será posible realizar un benchmarking de eficiencia y calidad y asignar recursos en función de los costes obtenidos en los diferentes procesos de la cartera de servicios socio sanitarios establecidos, algo imposible con los sistemas de información actuales.

Un SISS le permitirá a los gestores:

- registrar a los pacientes y asignarles un código identificativo;

- facilitar el seguimiento del proceso socio sanitario con una metodología ABQ [Activity Based Quality] enfocada en la calidad asistencial, conociendo cómo se realizan los procesos asistenciales socio sanitarios (Activity Based Management, ABM) y cuál es el coste de cada proceso (Activity Based Costing, ABC), todo ello tomando como eje del proceso al paciente con necesidades socio sanitarias que haya sido definido como persona susceptible de inclusión;

- poder realizar el seguimiento mediante un cuadro de mando de todo el proceso; y

- realizar una evaluación y benchmarking disponiendo de la información sanitaria y social que esté disponible en una HSSI, y que sea interoperable y accesible, tanto desde la parcela de lo social, como desde la parcela sanitaria.

Además del SISS, la HSSI y el CMBDSS, se va a requerir de un sistema de ajuste de riesgos a través de un Conjunto Agregado de Atención Social [CAAS] que permita conocer el coste de los procesos sociales, para poder realizar comparaciones (benchmarking) de eficiencia y calidad y asignar recursos en función de los cos- 
tes obtenidos en los diferentes procesos del catálogo de servicios sociales. Para ello, se requiere de la realización de unas Guías Integradas de Atención Social [GIAS] para la estandarización de los procesos y un nuevo Modelo de Asignación de Costes a los Procesos de Atención Social [MacPAS], para posteriormente definir una Herramienta para la Evaluación de Resultados en Atención Social [HERAS].

Un diagnóstico de las necesidades sociales, los objetivos de cobertura a alcanzar, las líneas estratégicas y las acciones idóneas para su consecución, y un pronóstico de su evolución son la base de la planificación, y los mecanismos de evaluación sistemática y continuada, su garantía de ejecución con calidad. Estas herramientas proporcionan transparencia en los acuerdos de servicio entre las empresas y los organismos proveedores y la administración que los financia.

Todo este marco de referencia de modelos, herramientas y metodologías forma el Modelo Integral de Gestión de Recursos Asistenciales en Atención Social (socio sanitarios) MIGRASS (ver Figuras 7 y 8), el cual sigue el patrón iniciado en sanidad, que ha originado productos como los Grupos Relacionados por el Diagnóstico [GRD], los Grupos Clínicos Ajustados [ACG] y otros similares; busca aspectos comunes en los usuarios de los servicios sociales que posibiliten el establecimiento de clasificaciones que permitan agrupar los procesos de atención, dotarlos de indicadores y poder comparar su desempeño y la efectividad de sus resultados.

Este nuevo modelo de gestión integrada va a permitir:

- registrar a los usuarios de servicios sociales de manera unívoca y tener una visión integral de los servicios que utilizan y su entorno familiar o de convivencia;

- facilitar el seguimiento del proceso social con una metodología ABQ enfocada en la calidad asistencial, conociendo cómo se realizan los ABM y cuál es ABC de cada proceso;

- poder hacer un seguimiento mediante un cuadro de mando de todo el proceso; y

- evaluar la efectividad de las acciones sociales disponiendo de una información social integrada.

De esta manera, aprovechando el impulso de la integración social, se sugiere complementarlo con el desarrollo de herramientas que efectivamente permitan planificar, diseñar, medir, comparar y provisionar el conjunto de nuestros procesos permitiendo:
All this frame of models reference, tools and methodologies constitutes the Management of Assistance Resources in Social Care Integral Model (Health Partner) [Modelo Integral de Gestión de Recursos Asistenciales en Atención Social (Socio sanitarios), MIGRASS] (see FIGURE 7 and 8), which follows the pattern initiated in health, which has originated products such as the Diagnosis-Related Groups [DRG], the Adjusted Clinical Groups [ACG] and similar ones. It also looks for common aspects in the social services users that allow the establishment of classifications and the attention processes arrangement, providing them with indicators and being able to compare their performance and their results effectiveness.

This new integrated management model will allow to:

- Register users of social services univocally and get a comprehensive view of the services they use and their family environment or coexistence;

- facilitate the monitoring of the social process with an ABQ methodology focused on the quality of care, knowing how the ABMs are performed and what is the ABC of each process;

- be able to follow up through a scorecard of the whole process; and

- evaluate the effectiveness of social actions by an integrated social information.

So, taking advantage of the social integration momentum, it is suggested to complement with the development of tools that effectively allow planning, designing, measuring, comparing, and provisioning the set of our processes allowing to:

- Identify and classify users;

- order and group the processes of our social services catalog in aggregate sets of social care;

- evaluate these processes and establish reference indicators;

- measure the execution of the processes through a tool that allows the actors to evaluate the performance of the institutions under their responsibility;

- analyze the results and predict the demand and resources consumption; and

- be able to make adjustments and planning.

One of the fundamental elements of MIGRASS is the tool for the costs allocation to social assistance processes, which is very useful for assessing the cost of each CAAS and for establishing and making comparisons. It is the 

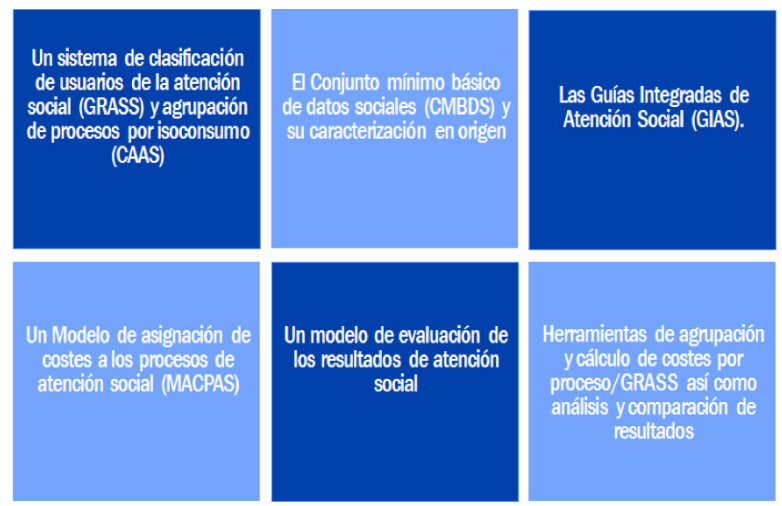

Figure 7. MIGRASS Model / Modelo MIGRASS
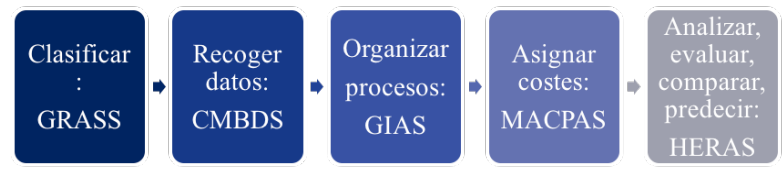

Figure 8. MIGRASS Model / Modelo MIGRASS

module of costs allocation derived from the GRASS and CAAS by citizen, for the different cost centers. It implements an accounting method that allocates the costs with a tree-like detail according to the total expenditure in a certain period of time.

MacPAS is the tool that allows modeling and defining a costs system associated with social care processes. Similar to other areas, the need for a cost model is evident in health. For that reason, a cost-setting system based on the ABC methodology is introduced as support for the social assistance processes. Its philosophy is based on the principle that activities are really the causes that determine the resources consumption and the subsequent costs. In the social field, this system identifies the activities carried out in the process and employs cost drivers that allow the costs of these activities to be transferred to the different products or services, depending on the social processes carried out. In that way, the centers or departments incur costs as long as they carry out activities, and the cost of the products results from the consumption of the activities necessary to obtain them.

A significant aspect of cost systems based on activities is their orientation towards activities. In this case, if reliable and correct information is generated, relative to those activities that are not important in social care, a significant reduction in the tasks or associated work could be achieved, which, in any case, would induce a costs reduction and a quality improvement.

Considering the ABC system, it should be noted that the cost measurement structure is conceived on each
- identificar y clasificar a los usuarios;

- ordenar y agrupar los procesos de nuestro catálogo de servicios sociales en conjuntos agregados de atención social;

- valorar dichos procesos e instaurar indicadores de referencia;

- medir la ejecución de los procesos mediante una herramienta que permita a todos los actores evaluar el desempeño de las instituciones a su cargo;

- analizar los resultados y predecir la demanda y el consumo de recursos; y

- poder realizar ajustes y planificación.

Uno de los elementos fundamentales del MIGRASS es la herramienta para la asignación de costes a los procesos de atención social, de gran utilidad para valorar el coste de cada CAAS y poder establecer y realizar comparativas. Constituye el módulo de asignación de costes derivados de los GRASS y CAAS por ciudadano, para los diferentes centros de coste e Implementa un método de contabilidad que asigna los costes con un detalle arborescente de acuerdo con el gasto total en un determinado periodo de tiempo.

MacPAS es la herramienta que permite modelar y definir un sistema de costes asociados a los procesos de atención social. Al igual que en otros ámbitos, en el de la salud se hace patente la necesidad de contar con un modelo de costes. Por ese motivo se introduce como soporte a los procesos de atención social un sistema de establecimiento de costes basado en la metodología ABC. Su filosofia se basa en el principio de que las actividades son realmente las causas que determinan el consumo de recursos y los costes subsiguientes. En el ámbito social, este sistema identifica las actividades realizadas en el proceso y emplea unos inductores de costes (cost drivers) que permiten llevar los costes de estas actividades a los distintos productos o servicios, en función de los procesos sociales realizados. De este modo, los centros o departamentos incurren en costes en la medida en que realizan actividades y el coste de los productos resulta del consumo de las actividades necesarias para obtenerlos.

Un aspecto significativo de los sistemas de costes basados en las actividades es que se encuentran orientados hacia las actividades. En este caso, si se llega a generar una información fiable y correcta, relativa a aquellas actividades que carecen de importancia en la atención social, se podría conseguir una importante reducción de 
las tareas o trabajos asociados que, en todo caso, induciría en mayor o menor medida una reducción de los costes y una mejora de la calidad.

Atendiendo al sistema ABC, cabe señalar que la estructura de medición de los costes se concibe sobre todos y cada uno de los centros de costes intervinientes, y recoge, por tanto, dentro de estas consideraciones, todos los costes asociados con la atención social del ciudadano, en todos los ámbitos posibles (Cabo-Salvador et al., 2017; Cabo-Salvador et al., 2018; Cabo-Salvador, 2017). Sostenibilidad del sistema sanitario (eficiencia) y mejora en la calidad asistencial

Durante la última década del siglo pasado hemos asistido a un crecimiento notable del sector de cuidados gerontológicos residenciales y no residenciales (centros de día, telealarma, servicios de ayuda a domicilio, etc.). El sector público ha promovido la creación de plazas para atención a personas mayores dependientes con diferentes modelos o sistemas de gestión. Apenas se han creado centros públicos de gestión pública y, por el contrario, la gestión privada de plazas públicas (gestión integral privada de centros públicos, gestión privada de plazas concertadas, financiación directa al usuario como cheque-bono asistencial, etc.) es la modalidad que el sector público considera más eficiente. Pero en esta modalidad de gestión, para la administración pública es imprescindible conocer la producción y la calidad de los servicios prestados.

Este objetivo es complicado de llevar a cabo debido a varias causas, entre ellas:

- la inmadurez del concepto de evaluación de los servicios;

- la insuficiente definición del catálogo de servicios del sector, que crea una enorme confusión cuando se pretende comparar estructuras de centros, carteras de servicios y programas, tipología de usuarios y resultados; y

- la inexistencia de un modelo de gestión de referencia que provoca que en cada centro prevalezca un modelo de gestión distinto y que profesionales o servicios que se desenvuelven en una actividad semejante, lo hagan bajo parámetros de producción no comparables.

En este camino, la universalidad e importancia de las situaciones de dependencia ha hecho que sean múltiples las disciplinas y los profesionales que se encarguen de su análisis, aportando multiplicidad de datos, aspecto que of the intervening cost centers, and therefore includes, within these considerations, all the costs associated with the social care of the citizen, in all possible areas (Cabo-Salvador et al., 2017; Cabo-Salvador et al., 2018; Cabo-Salvador, 2017).

\section{Health System Sustainability (efficien- cy) and Quality of Care Improvement}

During the last decade of the last century we have witnessed a remarkable growth of the residential and non-residential gerontological care sector (day centers, tele-alarm, home help services, etc.). The public sector has promoted the creation of places for dependent elderly people care with different models or management systems. Public management centers have scarcely been created. On the contrary, the private management of public places (private integral management of public centers, private management of agreed places, direct financing to the user as a check-bonus, etc.) is the modality that the public sector considers more efficient. However, according to this type of management, it is essential to know the production and quality of the services provided for public administration.

This objective is difficult to carry out due to several causes, among them:

- The concept of evaluation of services immaturity;

- the insufficient definition of the services catalog in the sector, which creates enormous confusion when comparing structures of centers, services portfolios and programs, users' types and results; and

- the lack of a reference management model that causes a different management model in each center, and that professionals or services from a similar activity perform under non-comparable production parameters.

In this way, the universality and importance of dependence situations has led to multiple disciplines and professionals who are responsible for their analysis, providing multiple data, which comes counterproductive, due to the diversity of activity scales and classification of users of social assistance methods (see Figure 9).

The main objective of the social health management integrated model as a whole is the analysis of the GRASS in the social assistance system, for use as a financing or budgetary tool in the Public System of Social Services. The above, through the proposal of a first in- 
ventory for related groups, designing as base the Social Space Minimum Basic Data Set [SSMBDS]. For each of the GRASS, it is necessary to develop the information related to the activities, consolidating a first approximation to the process standard or to its GIAS, which must include: A global process diagram, in which the different functional services are perfectly identified, carrying out activities throughout it; the interrelationships between them; and the resources used (time and materials).

Once the resources are known, the costs are imputed, in order to obtain the cost per process. The direct costs (personnel, materials and assistance) would be derived from the description made in the GIAS. To calculate the indirect costs, it is necessary to allocate them based on some distribution criteria determined in a consensual manner with the competent authorities in the management of social services. The latest phase requires information from historical databases and participatory decision-making with those directly responsible for social services and processes (Cabo-Salvador et al., 2017; Cabo-Salvador et al., 2018; Cabo-Salvador, 2017).

\section{Efficient and Quality Social-Healthcare}

Nowadays, there is a generalized awareness of the important contribution that new ICTs have in our society, mainly in aspects related to the health and well-being of people since we tend towards an aging population, in which people become chronic patients with multiple pathologies that need continuous care over time. The traditional acute patient profile is changing, he needs, not only timely access to health resources at acute illness times but coordinated attention and care through different types of socio-health specialists, with the purpose to receive appropriate treatment with your needs. The current acute ma-

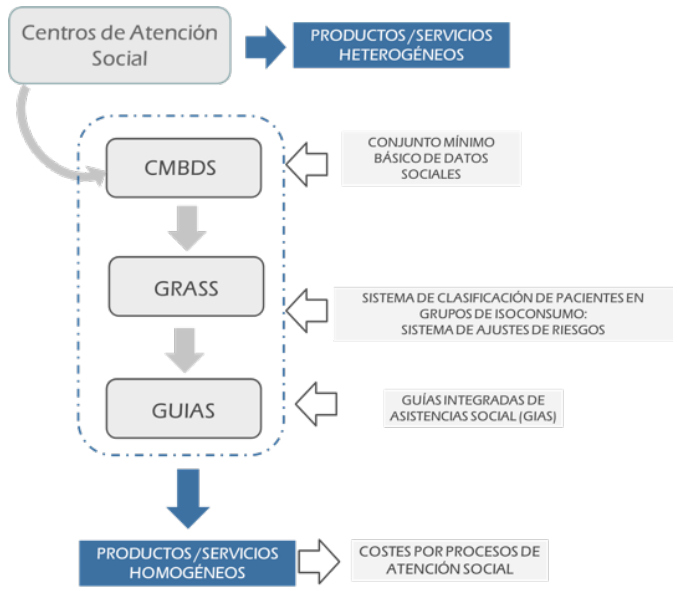

Figure 9. Products and services homogenization schematic model / Modelo esquemático de la homogeneización de los productos y servicios viene a ser, de algún modo contraproducente, al existir diversidad de escalas de actividad y métodos de clasificación de usuarios de la asistencia social (ver Figura 9).

El objetivo principal del modelo integrado de gestión socio sanitaria en su conjunto es el análisis de los GRASS en el sistema de asistencia social, evaluando este sistema de agrupación, para su utilización como herramienta de financiación o presupuestaria en el Sistema Público de Servicios Sociales, proponiendo un primer inventario de grupos relacionados de diseñando como base el Conjunto Mínimo Básico de Datos del Espacio Social [CMBDS]. Para cada uno de los GRASS se elabora la información relativa a las actividades que desarrolla, consolidando una primera aproximación al estándar del proceso o a su GIAS, la cual debe incluir: un diagrama global del proceso, en el que quedan perfectamente identificados los diferentes servicios funcionales que intervienen realizando actividades a lo largo del mismo; las interrelaciones entre ellas; y los recursos empleados para ello (tiempo y materiales).

Una vez conocidos los recursos que se emplean, se procede a imputar los costes, para así obtener el coste por proceso. Los costes directos (personal, materiales y asistencia) se derivarían de la descripción efectuada en las GIAS; para calcular los costes indirectos es preciso imputarlos con base en unos criterios de reparto determinados de manera consensuada con las autoridades competentes en la gestión de los servicios sociales. Esta última fase requiere de información de bases de datos históricas y de la toma de decisiones participativa en conjunto con los responsables directos implicados en los servicios y procesos sociales (Cabo-Salvador et al., 2017; Cabo-Salvador et al., 2018; Cabo-Salvador, 2017). Atención socio-sanitaria eficiente y de calidad En estos momentos existe una conciencia generalizada de la importante contribución que las nuevas TIC tienen en nuestra sociedad, en particular en los aspectos relacionados con la salud y el bienestar de las personas, debido a que tendemos hacia una población envejecida, en la que las personas se convierten en pacientes crónicos con pluripatologías que necesitan un cuidado continuo a lo largo del tiempo. El perfil del paciente agudo tradicional está cambiando, hoy necesita, no solo del acceso puntual a los recursos sanitarios en momentos agudos de enfermedad, sino de atención y cuidado coordinados por medio de distintos tipos de especialistas socio-sanitarios, para poder recibir un tratamiento acorde con sus 
necesidades. No es útil el modelo actual de gestión de agudos, un modelo sanitario basado en la atención puntual a situaciones críticas de salud y atención especializada en centros de salud u hospitales. En el cambio de modelo sanitario tenemos que incluir nuevos actores y servicios en la cadena de valor y hacer un cambio radical en la concepción del sistema sanitario, tendiendo a un sistema sanitario matricial y centrado en el paciente, en el que actúan médicos, enfermeros y otros profesionales socio-sanitarios que interactúan de una manera integral en el caso (Barr et al., 2003; Beaglehole et al., 2008; Bodenheimer \& Berry-Millett, 2009; Boult et al., 1999; ; Cabo-Salvador et al., 2017; Cabo-Salvador et al., 2018; Cabo-Salvador, 2017; Gravelle et al., 2007; Hébert et al., 2009; Kane et al., 2002; MacAdam, 2008; Oeseburg et al.2009; Ouwens et al., 2005; Pearson et al., 2005; Rosen \& Ham, 2008; Singh, 2005; Sylvia et al., 2008; Vickers et al., 2006; Weiss, 2007; Wolff et al., 2009; Zwar et al., 2006).

Aquí es donde las TIC pueden ser una herramienta clave en este proceso de cambio. Gracias al uso de soluciones de telemedicina y teleasistencia es posible proporcionarle a las personas mayores servicios socio-sanitarios en su propia casa, con costes muy razonables, no abordables de otra manera. Es posible disponer de herramientas de trabajo colaborativo, a partir de su integración con sistemas de HCE interoperables, que permitan a los profesionales socio-sanitarios acceder a toda la información pluripatológica de un paciente teniendo en cuenta y coordinando a todos los actores de la cadena de valor que satisface las necesidades del paciente crónico. A su vez, las redes sociales permitirán dotar de herramientas de autocuidado y autogestión a los mayores, como ya está sucediendo, permitiéndoles abordar problemas comunes como la soledad, la depresión y la falta de movilidad, los cuales degeneran en problemas físicos y psicológicos que deterioran el estado de salud de la persona.

Además, este modelo ofrece una atención más cercana y especializada para pacientes con uno o varios problemas crónicos de salud. Ellos son algunos de los principales beneficiados de este tipo de atención, mucho más continuada e individualizada, que da en todo momento mayor seguridad a las personas, sus familias y cuidadores.

El aumento de años en la esperanza de vida, el incremento de personas con pluripatologías, los cambios de roles en los cuidados de las familias españolas y la aplicación, al ámbito sanitario, de las TIC obligan a los nagement model is not useful. So, it is necessary to have a health model based on timely attention to critical health situations and specialized care in health centers or hospitals. In the change of health model it is required to include new actors and services in the value chain, and make a radical change in the conception of the health system, considering a patient-centered matrix health system, with doctors, nurses and other socio-health professionals who interact in a comprehensive manner in the case (Barr, et al. 2003; Beaglehole et al., 2008; Bodenheimer \& Berry-Millett, 2009; Boult et al., 1999; Cabo-Salvador et al., 2017; Cabo-Salvador et al., 2018; Cabo-Salvador, 2017; Gravelle et al., 2007; Hébert et al., 2009; Kane et al., 2002; MacAdam, 2008; Oeseburg et al., 2009; Ouwens et al., 2005; Pearson et al., 2005; Rosen \& Ham, 2008; Singh, 2005; Sylvia et al., 2008; Vickers et al., 2006; Weiss, 2007; Wolff et al., 2009; Zwar et al., 2006).

At this point, ICT can be a key tool in this process of change. Thanks to the use of telemedicine and telecare solutions it is possible to provide elderly people with social-health services in their own home, and with affordable costs, which cannot be addressed in any other way. It is possible to have collaborative work tools, based on their integration with interoperable HCE systems, which allow socio-health professionals to access all the patient's multi-pathological information, and coordinating all the actors in the healthcare value chain that meets the needs of the chronic patient. On the other hand, social networks will provide tools for the elderly self-care and self-management, allowing them to address common problems such as loneliness, depression, and lack of mobility, which degenerate into physical and psychological problems that deteriorate the state of health of the person.

In addition, this model offers closer and specialized care for patients with one or more chronic health problems. They are some of the main beneficiaries of this type of care, much more continuous and individualized, which gives greater security to people, their families and caregivers at all times.

The increase of years in the life expectancy, the increase of people with multiple pathologies, the changes of roles in the care of Spanish families and the application to the ICT sanitary field, assist health managers to reorient their organizations and change their strategies, establishing tactical alternatives to face these new challenges. In addition, it is important to consider that the cost of patients with more than one chronic disease 
multiplies exponentially with respect to those who are only carriers of a disease (Cabo-Salvador et al., 2017; Cabo-Salvador et al., 2018; Cabo-Salvador, 2017).

\section{Conclusions}

It is necessary to reorganize and manage efficiently the social and healthcare models, considering primary care as a predominant role, with greater care integration between primary care and hospital care, improving interoperability and continuity of care between them.

New integrated management models by processes are needed through an evidence-based medicine, using consensus clinical guidelines and case management where the family members or socio-healthcare providers play an important role in the process of chronic patient care.

It is necessary to manage diseases, with an increase, both in preventive medicine and in proactive medicine, focused on the patient, and through an adequate socio-sanitary attention to their needs in their closest environment (Home Care), in order to avoid patient displacements, unnecessary hospital admissions, and an indiscriminate use of emergency services.

All the above have an impact on a better quality of care and on the reduction of structural and functional costs, as a result of the decrease of the number of emergencies, hospital consultations, and hospital admissions; as well as the decrease of the diagnostic tests duplicity; and interactions and drug iatrogenies. It will result in a decrease of health expenses, system inefficiencies, and existing bottlenecks. Sat responsables sanitarios a reorientar sus organizaciones y cambiar sus estrategias, estableciendo alternativas tácticas para afrontar estos nuevos desafíos. Además, es importante considerar que el coste de los pacientes con más de una enfermedad crónica se multiplica exponencialmente con respecto de los que sólo son portadores de una enfermedad (Cabo-Salvador et al., 2017; Cabo-Salvador et al., 2018; Cabo-Salvador, 2017).

\section{Conclusiones}

Es necesaria la reorganización y gestión eficiente de los modelos sociales y asistenciales, dando un papel preponderante a la atención primaria, con una mayor integración asistencial entre la atención primaria y la atención hospitalaria, mejorando la interoperabilidad y la continuidad asistencial entre ambos.

Se necesitan nuevos modelos integrados de gestión por procesos mediante una medicina basada en la evidencia, empleando guías clínicas consensuadas y con la gestión de casos donde el núcleo familiar o los cuidadores socio-sanitarios cobren un papel relevante en el proceso de atención del paciente crónico.

Es necesaria una gestión de enfermedades, con incremento, tanto de la medicina preventiva, como de la medicina proactiva, con un enfoque centrado en el paciente, aportando la atención socio-sanitaria adecuada a su necesidad en su entorno más cercano (Home Care), evitando en muchos casos desplazamientos de los pacientes e ingresos hospitalarios innecesarios y el uso indiscriminado de los servicios de urgencias.

Todo esto repercutirá en una mejor calidad asistencial y en la disminución de los costes estructurales y funcionales, como efecto de la disminución: del número de urgencias y consultas hospitalarias e ingresos hospitalarios; de la duplicidad de pruebas diagnósticas; y de las interacciones e iatrogénias medicamentosas, y redundará en una disminución del gasto sanitario y la disminución de ineficiencias del sistema y de los cuellos de botella existentes.ST 


\section{References / Referencias}

Arshad, P., Oxley, H., Watts, S., Davenport, S., \& Sermin, N. (2000). Systematic approach to community risk assessment and management. Br J Nurs., 9(4), 210-214.

Barr, V., Robinson, S., Marin-Link, B., Hunderhill, L., Dotts, A., Ravensdale, D., \& Salivaras, S. (2003). The expanded chronical care model. Hospital Quaterly, 7(1), 73-82.

Beaglehole, R.B., Epping-Jordan, J.E., Patel, V., Chopra, M., Ebrahim, S., Kidd, M., \& Haines, A. (2008). Improving the prevention and management of chronic disease in low-income and middle-income countries: a priority for primary health care. The Lancet, 372(9642), 940-949.

Bengoa, R., Nuño, R. (2008). Curar y cuidar. Innovación en la gestión de enfermedades crónicas: una guía práctica para avanzar. Barcelona, España: Elsevier-Masson.

Bodenheimer, T. \& Berry-Millett, R. (2009). Care management of patients with complex health care needs. Princeton, NJ: Robert Wood Johnson Foundation.

Boult, C., Kane, R.L., \& Brown, R. (2000). Managed care of chronically ill older people: The US experience. BMJ, 321(7267), 1011-1014.

Boult, C., Kane, R.L., Pacala, J.T., \&Wagner, E.H. (1999). Innovative healthcare for chronically ill older persons: Results of a national survey. Am J Managed Care, 5(9), 1162-1172.

Boult, C., Reider, L., Frey, K., Leff, B., Boyd, C.M. ... Scharfstein, D. (2008). Early effects of "Guided Care" on the quality of health care for multimorbid older persons: A cluster-randomized controlled trial. J Gerontol Med Sci., 63A(3), 321-327.

Boult, C., Shadmi, E., Leff, B., Brager, R., Dunbar, L., Wolff, J.L., \& Wegener, S. (2007). Guided care for multi-morbid older adults. Gerontologist, 47(5), 697-704.

Busse, R., Blümel, M., Scheller-Kreinsen, D., \& Zentner, A. (2009). Managing chronic disease in Europe: The initiative for sustainable healthcare financing in Europe. Retrieved from: http://www.sustainhealthcare.org/navigation/CDM

Cabo-Salvador, J. \& Bellmont, M.A. (2014). Sistemas sanitarios y reformas sanitarias: enfoque hacia la calidad. In: J. Cabo-Salvador. (Ed.), Gestión de la calidad en las organizaciones sanitarias (pp. 1-48). Madrid, España: Diaz de Santos.

Cabo-Salvador, J. (2017). El impacto de la u-health, inteligencia artificial, robótica y nanotecnología en la medicina y el derecho. Proceedings XXIV Congreso Nacional de Derecho Sanitario, (pp.1-43). Madrid, España.

Cabo-Salvador, J., Bellmont, M.A., Cabo, J., \& Cabo, V. (2014). Ajustes de riesgos y calidad asistencial. Agrupadores (APG, GRD, AP-GRD, IR-GRD, ACG, DxCG, CRG). In: J. Cabo-Salvador. (Ed.), Gestión de la calidad en las organizaciones sanitarias (pp. 1157-1210). Madrid, España: Diaz de Santos.

Cabo-Salvador, J., Bellmont, M.A., Cabo, J., \& Herreros, J. (2010). Estructura organizativa, financiación, gasto, provisión de servicios y desarrollo de los sistemas sanitarios en los países de la Comunidad Económica Europea. In: J. Cabo-Salvador. (Ed.), Gestión sanitaria integral: pública y privada (pp. 85- 133). Madrid, España: Centro de Estudios Financieros

Cabo-Salvador, J., Bellmont, M.A., Cabo, V., Herreros, J., López, M., Sajardo, S., Ramos, J., \& Velarde, J. (2014). Gestión de la eficiencia y calidad asistencial en las organizaciones sanitarias. In: J. Cabo-Salvador. (Ed.), Gestión de la calidad en las organizaciones sanitarias (pp. 371-409). Madrid, España: Diaz de Santos.

Cabo-Salvador, J., Bellmont, M.A., Herreros, J., \& Cabo, J. (2014). Estudios de Evaluación Económica de Nuevas Tecnologías y Terapias Asistenciales con enfoque a la calidad asistencial. In: J. Cabo-Salvador. (Ed.), Gestión de la calidad en las organizaciones sanitarias (pp. 1207-1270). Madrid, España: Diaz de Santos.

Cabo-Salvador, J., Cabo, J., \& Iglesias, R. (2010). Sistemas de salud y reformas sanitarias en España, Canadá y Estados Unidos. In: J. Cabo-Salvador (Ed.), Gestión sanitaria integral: pública y privada, (pp. 31- 84). Madrid, España: Centro de Estudios Financieros.

Cabo-Salvador, J., de Castro C, Cabo, V., Ramos, J., \& López, M. (2017). El futuro de la IPTV integrada con la inteligencia artificial en la gestión socio sanitaria integrada. In: Proceedings of the 6th Iberoamerican Conference on Disease Management: Applications and Usability for Interactive TV. JAUTI ( pp.115-129).

Cabo-Salvador, J., Herreros, J., Cabo, V., Bellmont, M.A., García, E., \& Vilches, M. (2014). Plan estratégico de gestión de las organizaciones sanitarias: gestión clínica y gobierno clínico. In: Reunió d'experts: Innovant en prevenció cardiovascular $i$ eficiencia. Barcelona, España: Price Waterhouse Coopers.

Cabo-Salvador, J., Ramirez-Uceda JM, Cabo, V., Ramos, J., \& de Castro, C. (2018). Ubiquitous computing and its applications in the disease management in a ubiquitous city. Journal of Computer and Communications, 6(3), 19. doi:10.4236/ jcc.2018.63002

Cabo-Salvador., J. \& Unda, E. (2010). Sistemas de ajuste de riesgos (AP-GRDs, APR-GRDs, IR-GRDs, CRGs, DxCGs): gestión por procesos y benchmarking. In: J. Cabo-Salvador. (Ed.), Gestión sanitaria integral: pública y privada (pp. 453- 512). Madrid, España: Centro de Estudios Financieros.

Clark, C.M Jr., Snyder, J.W., Meek, R.L., Stutz, L.M., \& Parkin, C.G. (2001). A systematic approach to risk stratification and intervention within a managed care environment improves diabetes outcomes and patient satisfaction. Diabetes Care, 24(6), 1079-1086.

Coleman, K., Austin, B.T., Brach, C., \& Wagner, E.H. (2009). Evidence on the chronic care model in the new millennium. Health Affairs, 28(1), 75-85.

Curtis, L. (comp.). (2012). Unit costs of health and social care 2012. Canterbury, UK: University of Kent.

de Castro, C., Cabo-Salvador, J., Ramírez, J.M., \& García, E. (2014). SIESTACARE: inteligencia ambiental aplicada a sistemas e-salud como tecnología de ayuda a enfermos y personas en situaciones de dependencia. In: J. Cabo-Salvador. (Ed.), Gestión de la calidad en las organizaciones sanitarias, (pp. 953- 1008). Madrid, España: Diaz de Santos. 
Drennan, V. \& Goodman, C. (2004). Nurse-led case management for older people with long-term conditions. Br J Community Nurs., 9(12), 527-533.

Epping-Jordan, J.E., Pruitt, S.D., Bengoa, R., \& Wagner, E.H. (2004). Improving the quality of health care for chronic conditions. Quality and Safety in Health Care, 13(4), 299-305.

Evercare (n.d). Implementing the Evercare program: Interim report. Retrieved from: http://www.natpact.info/cms/186.php

Fussell, E. (2006). Leaving New Orleans: Social stratification, networks, and hurricane evacuation. Social Science Research Council 2006; June 11. Retrieved from: http://understandingkatrina.ssrc.org/Fussell/

Gilmer, T.P., O'Connor, P.J., Rush, W.A., Crain, A.L., Whitebird, R.R., Hanon, A.M., \& Solberg, L.I. (2006). Impact of office systems and improvement strategies on costs of care for adults with diabetes. Diabetes Care, 29(6):1242-1248.

Gravelle, H., Dusheiko, M., Sheaff, R., Sargent, P., Boaden, R., Pickard, S., Parker, S., \& Roland, M. (2007). Impact of case management (Evercare) on frail patients: Controlled before and after analysis of quantitative outcome data. BMJ, 334(7583), 31-34.

Gonseth, J., Guallar-Castillón, P., Banegas, J.R., \& Rodríguez-Artalejo, F. (2004). The effectiveness of disease management programmes in reducing hospital re-admission in older patients with heart failure: A systematic review and meta-analysis of published reports. Eur Heart J., 25(18):1570-1595.

Goodwin, N. \& Curry, N. (2008). Methods for predicting risk of emergency hospitalization. In: 8th INIC Annual Conference. Gothenburg; 7th March 2008.

Health and Social Care Information Centre [HSCIC]. (2015). Personal social services expenditure and unit costs, England, 2014-15: Final release. London, UK: HSCIC.

Hébert, R., Raîche, M., Dubois, M. F., Gueye, N. D. R., Dubuc, N., Tousignant, M., \& PRISMA Group. (2009). Impact of PRISMA, a coordination-type integrated service delivery system for frail older people in Quebec (Canada): A quasi-experimental study. Journals of Gerontology Series B: Psychological Sciences and Social Sciences, 65(1), 107-118.

Herreros, J. \& Cabo-Salvador, J. (2014). Calidad y efectividad en las organizaciones sanitarias. sistemas de información, adecuación de recursos y gestión de riesgos. In: J. Cabo-Salvador. (Ed.), Gestión de la calidad en las organizaciones sanitarias, (pp. 345-379). Madrid, España: Diaz de Santos.

Hroscikoski, M.C., Solberg, L.I., Sperl-Hillen, J.M., Harper, P.G., McGrail, M.P., \& Crabtree, B.F. (2006). Challenges of change: a qualitative study of chronic care model implementation. Ann Fam Med., 4(4):317-326.

Jhon Hopkins University (2010). The Johns Hopkins ACG® System: Technical Reference Guide version 10.0. Baltimore, MD: Jhon Hopkins University.

Kane, R., Keckhafer, G., \& Robst, J. (2002). Evaluation of the Evercare demonstration program: Final report to the centers for medicare and medicaid services. Minneapolis, MN: University of Minnesota.

Kane, R.L., Keckhafer, G., Flood, S., Bershadsky, B., \& Siadaty, M.S. (2003). The effect of Evercare on hospital use. J Am Geriatr Soc., 51(10), 1427-1434.

Kreindler, S. (2008). Lifting the burden of chronic disease. Winnipeg, MB: Winnipeg Regional Health Authority.

López, M., de la Torre, I., Herreros, J., Cabo-Salvador, J. (2014). Mejora de la Calidad Asistencial mediante la Telemedicina y la Teleasistencia. In: J. Cabo-Salvador. (Ed.), Gestión de la calidad en las organizaciones sanitarias, (pp. 933-952). Madrid, España: Diaz de Santos.

MacAdam, M. (2008). Frameworks of integrated care for the elderly: A systematic review. Toronto, ON: Canadian Policy Research Networks.

MacColl Institute for Health Care Innovation. (2013). Chronic care model [image]. Retrieved from: http://www.maccollcenter. org/resources/chronic-care-model

Medicare Payment Advisory Commission [MedPAC]. (2007). Report to Congress: Promoting greater efficiency in Medicare. Washington, DC: MedPAC.

Morgan, M.W., Zamora, N.E., \& Hindmarsh, M.F. (2007). An inconvenient truth: A sustainable healthcare system requires chronic disease prevention and management transformation. Healthcare Papers, 7(4), 6-23.

National Public Health Service for Wales. (2006). International overview of the evidence on effective service models in chronic disease management. Cardiff, Wales: Welsh Assembly Government.

Nolte, E. \& McKee, M. (Eds). (2008). Caring for people with chronic conditions: A health system perspective. Maidenhead, UK: Open University Press.

Norris, S.L., Nichols, P.J., Caspersen, C.J., Glasgow, R.E., Engelgau, M.M., ... \& McCulloch, D. (2002). The effectiveness of disease and case management for people with diabetes: A systematic review. Am J Prev Med.,22(4 Suppl), 15-38.

Observatorio de Prácticas Innovadoras para el Manejo de Enfermedades Complejas [OPIMEC]. (2018).Glosario sobre enfermedades crónicas complejas. Retrieved from: http://www.opimec.org/glosario/

Oeseburg, B., Wynia, K., Middel, B., \& Reijneveld, S.A. (2009). Effects of case management for frail older people or those with chronic illness: a systematic review. Nurs Res., 58(3), 201-210.

Ollero. M. (Coord.). (2002). Atención al paciente pluripatológico: Proceso asistencial integrado. Sevilla, España: Consejería de Salud; 2002.

Organización de las Naciones Unidas [ONU]. (2017). Envejecimiento. Retrieved from: http://www.un.org/es/sections/issues-depth/ageing/index.html

Organization for Economic Co-operation and Development [OECD]. (2017). Health at a glance 2017: OECD indicators. Paris, France: OECD 
Ouwens, M., Wollersheim, H., Hermens, R., Hulscher, M., \& Grol, R. (2005). Integrated care programmes for chronically ill patients: a review of systematic reviews. Int J Qual Health Care, 17(2):141-146.

Ovretveit, J. \& Staines, A. (2007). Sustained improvement? Findings from an independent case study of the Jönköping quality program. Qual Manag Health Care, 16(1), 68-83.

Parchman, M.L., Zeber, J.E., Romero, R.R., \& Pugh, J.A. (2007). Risk of coronary artery disease in type 2 diabetes and the delivery of care consistent with the chronic care model in primary care settings: A STARNet study. Med Care, 45(12), 1129-1134.

Parchman, M. \& Kaissi, A.A. (2009). Are elements of the chronic care model associated with cardiovascular risk factor control in type 2 diabetes? Jt Comm J Qual Patient Saf., 35(3), 133-138.

Pearson, M.L., Wu, S., Schaefer, J., Bonomi, A.E., Shortell, S.M., ... \& Keeler, E.B.(2005). Assessing the implementation of the chronic care model in quality improvement collaboratives. Health Serv Res., 40(4), 978-996.

Ramos, J., Soguero, C., Mora, I., Rojo, J.L., \& Cabo-Salvador. J. (2014). M-Health y su impacto en la calidad asistencial. In: J. Cabo-Salvador. (Ed.), Gestión de la calidad en las organizaciones sanitarias, (pp. 1009-1052). Madrid, España: Diaz de Santos.

Ramsey, F., Ussery-Hall, A., Garcia, D., McDonald, G., Easton, A., Kambon, M., ... \& Vigeant, J. (2008). Prevalence of selected risk behaviors and chronic diseases--Behavioral Risk Factor Surveillance System (BRFSS), 39 steps communities, United States, 2005. MMWR Surveill Summ, 57(11), 1-20.

Real Decreto-Ley 16/2012. (2012, abril 22). Boletín Oficial del Estado, Núm. 98 (Sec. I. p. 31278). Madrid, España.

Rosen, R. \& Ham, C. (2008). Integrated care: Lessons from evidence and experience. Birmingham, UK: Nuffield Trust.

Russell, G., Thille, P., Hogg, W., \& Lemelin, J. (2008). Beyond fighting fires and chasing tails? Chronic illness care plans in Ontario, Canada. Ann Fam Med. 6(2), 146-153.

Sevick, M.A., Trauth, J.M., Ling, B.S., Anderson, R.T., Piatt, G.A., Kilbourne, A.M., \& Goodman, R.M. (2007). Patients with complex chronic diseases: perspectives on supporting self-management. J Gen Intern Med., 22 (suppl 3), 438-444.

Sheaff, R., Boaden, R., Sargent, P., Pickard, S., Gravelle, H., Parker, S., \& Roland, M. (2009). Management for frail elderly people: A qualitative study. J Health Serv Res Policy., 14(2), 88-95.

Shojania, K.G., Ranji, S.R., McDonald, K.M., Grimshaw, J.M., Sundaram, V., Rushakoff, R.J., \& Owens, D.K. (2006). Effects of quality improvement strategies for type 2 diabetes on glycemic control: A meta-regression analysis. Journal of the American Medical Association, 296(4), 427-440.

Singh, D. (2005). Transforming chronic care: evidence about improving care for people with long-term conditions. Birmingham, UK: University of Birmingham.

Sperl-Hillen, JM. (2004). Do all components of the chronic care model contribute equally to quality improvement? Joint Commission journal on quality and safety, 30(6), 303-309.

Sylvia, M.L., Shadmi, E., Hsiao, C.J., Boyd, C.M., Schuster, A.B., \& Boult, C. (2006). Clinical features of high-risk older persons identified by predictive modeling. Dis Manag., 9(1), 56-62.

Sylvia, M., Griswold, M., Dunbar, L., Boyd, C.M., Park, M., \& Boult, C. (2008). Guided care: Cost and utilization outcomes in a pilot study. Dis Manag., 11(1), 29-36.

Tinetti, M.E., Bogardus, S.TJr., \& Agostini, J.V. (2004). Potential pitfalls of specific disease guidelines for patients with multiple conditions. N Eng/ J Med., 351(27):2870-2874.

Tracy, C.S., Dantas, G.C., \& Moineddin, R. (2003). The nexus of evidence, context, and patient preferences in primary care: postal survey of Canadian family physicians. BMC Fam Pract., 4(13). doi: 10.1186/1471-2296-4-13.

Vickers, A.J., Kramer, B.S., \& Baker, S.G. (2006). Selecting patients for randomized trials: a systematic approach based on risk group. Trials, $7(1), 30$.

Wagner, E.H. (1998). Chronic disease management: what will it take to improve care for chronic illness? Effective Clin Practice, 1(1), 2-4.

Wagner, E.H., Austin, B.T., \& Von-Korff, M. (1996). Organizing care for patients with chronic illness. Milbank Quarterly, 74(4), 511-544.

Wagner, E.H., Davis, C., Schaefer, J., Von-Korff, M., \& Austin, B. (1999). A survey of leading chronic disease management programs: are they consistent with the literature? Managed Care Quart, 7(3), 56-66.

Wagner, E.H., Sandhu, N., Newton, K.M., McCulloch, D.K., Ramsey, S.D., \& Grothaus, L.C . (2001). Effect of improved glycemic control on health care costs and utilization. JAMA, 285(2), 182-189.

Weiss, K.B. (2007). Managing complexity in chronic care: An overview of the VA state-of-the-art (SOTA) conference. J Gen Intern Med.,22(Suppl 3), 374-378.

Wolff, J.L., Rand-Giovannetti, E., Palmer, S., Wegener, S., Reider, L., Frey, K., \& Boult, C. (2009), Caregiving and chronic care: The guided care program for families and friends. J Gerontol Med Sci., 64A(7), 785-791.

World Health Organization [WHO]. (2002). Innovative care for chronic conditions: building blocks for action [Global report WHO/NMC/CCH]. Geneva, Switzerland: WHO.

Zwar, N., Harris, M., Griffiths, R., Roland, M., Dennis, S., Powell, D. \& Hasan, I. (2006). A systematic review of chronic disease management. Canberra, Australia: Australian Primary Health Care Research Institute. 


\section{CURRICULUM VITAE}

Javier Cabo Salvador Doctor in Medicine and Surgery from the Universidad Autónoma de Madrid (Spain). Fellowship in Cardiovascular Surgery at the Universities of Harvard (Cambridge, MA), Washington (Seattle, WA), Loma Linda (CA) and Pennsylvania (Philadelphia, PA). Medical Specialist in Cardiovascular Surgery. Honorary Doctor from the Universidad Central del Este and from the Universidad Católica Nosdestana (República Dominicana). Member of the New York Academy of Sciences and the International Who's Who Historical Society. Director of the Chair of Biomedical Research at the Universidad Internacional de Andalucia (Spain). Director of the Health Sciences Department and the Chair of Health Management at the Universidad de Madrid [UDIMA]. Director of the Chair of Biomedical Research at the Universidad Católica Nordestana. Director of the Cardiovascular Department at the Hospital Vithas Nisa Pardo (Aravaca, Spain).Member of the Health Advisory Council for the Government of Spain. Member of the National Commission of Specialists in Cardiovascular Surgery of the Ministry of Health; Advisory Member of the National Institute of Health Management. Member of the Panel of Experts of the Spanish Agency of Medicines and Health Products of the Government of Spain / Doctor en Medicina y Cirugía de la Universidad Autónoma de Madrid (España). Fellowship en Cirugía Cardiovascular en las Universidades de Harvard (Cambridge, MA), Washington (Seattle, WA), Loma Linda (CA) y Pensilvania (Filadelfia, PA). Médico Especialista en Cirugía Cardiovascular. Doctor Honoris Causa de la Universidad Central del Este y de la Universidad Católica Nosdestana de la República Dominicana. Miembro de la Academia de Ciencias de New York y de la International Who's Who Historial Society. Director de la Cátedra de Telemedicina en la Universidad Internacional de Andalucía (España). Director del Departamento de Ciencias de la Salud y de la Cátedra de Gestión Sanitaria de la Universidad de Madrid [UDIMA]. Director de la Cátedra de Investigación Biomédica de la Universidad Católica Nordestana. Director del Departamento Cardiovascular del Hospital Vithas Nisa Pardo de Aravaca (España). Miembro del Consejo Asesor de Sanidad del Gobierno de España. Miembro de la Comisión Nacional de Especialistas en Cirugía Cardiovascular del Ministerio de Sanidad; Vocal Asesor del Instituto Nacional de Gestión Sanitaria. Miembro del Panel de Expertos de la Agencia Española de Medicamentos y Productos Sanitarios del Gobierno de España.

José Manuel Velarde Gestera Partner of Drimay Consultores. Specialist in planning, analysis, design, development and implementation of health and socio-health information systems. Degree in physics. Advanced Management Program (Instituto de Empresa). Member of the Academic Committee of the Master of the Universidad de Sevilla (Spain): Design, implementation and operation of socio-health information systems. Its activities include: the direction of the development and implementation of the Diraya program for the Andalusian Health Service; the design and implementation of the Citizen Attention Center (Salud Responde) for the of Health Counseling of the Junta de Andalucia; the Information Systems Plan for the Ministry of Health of Tunisia; the Integrated Health Management System for the State of Acre (Brazil); the electronic prescription systems; the elaboration of the Integral Model of Management of Results in the Socio-Sanitary Attention (MIGRASS); and the creation of context analysis for the measurement of efficiency in public management / Socio de Drimay Consultores. Especialista en planificación, análisis, diseño, desarrollo e implantación de sistemas de información sanitarios y socio-sanitarios. Licenciado en Física. Advanced Management Program (Instituto de Empresa). Miembro de la comisión académica del Máster de la Universidad de Sevilla: Diseño, implantación y explotación de sistemas de información socio-sanitarios. Entre sus actividades se destacan: la dirección del desarrollo e implantación del programa Diraya para el Servicio Andaluz de Salud; el diseño e implantación del Centro de Atención al Ciudadano (Salud Responde) para la consejería de Salud de la Junta de Andalucía; el Plan de Sistemas de Información del Ministerio de Sanidad de Túnez; el Sistema integrado de gestión de la salud del Estado de Acre (Brasil); los sistemas de receta electrónica; la elaboración de Modelo Integral de Gestión de Resultados en la Atención Socio-Sanitaria (MIGRASS); y la creación del análisis de contexto para la medición de la eficiencia en la gestión pública. 
Verónica Cabo Muíños Degree in Pharmacy from the Universidad Complutense de Madrid (Spain). Specialty in Clinical Analysis (MIR training) in the Biochemistry Service at the Hospital Virgen de la Salud in Toledo (Spain). Specialist in Management of Assistance Processes with ABQ Methodology and Master in Advanced Clinical Management from the Universidad a Distancia de Madrid (UDIMA). Specialist in Human Reproduction Assisted from the Universidad de Salamanca (Spain). She is Director of Assistance Projects for IHM-Medical Technology / Licenciada en Farmacia por la Universidad Complutense de Madrid (España). Especialidad en Análisis Clínicos (formación MIR) en el Servicio de Bioquímica del Hospital Virgen de la Salud de Toledo (España). Especialista en Gestión de Procesos Asistenciales con Metodología ABQ y Máster en Gestión Clínica Avanzada por la Universidad a Distancia de Madrid (UDIMA). Especialista en Reproducción Humana Asistida por la Universidad de Salamanca. Es Directora de Proyectos Asistenciales de IHM-Medical Technology.

Carlos de Castro Lozano Doctor of Sciences from the University de Córdoba [UCO], Spain. Professor of Systems Engineering of the Computing Department of the UCO, expert in multimedia systems, human computer interaction, usability and Web accessibility, and interactive systems. Director of the Digital Contents Experimentation and Production Center of the UCO (Red.es) and the CRUE (CITEC). Director of the EATCO (Teaching and Learning by Communication Technologies) research group. Scientific director and creator of the products: iFreeTablet, iFreeTV, iFreeSIN, iFreemovil, Siesta, SiestaTV, SiestaCare, SiestaDomo, Wikicourses, and Tu-Learning. Responsible for wikicourses at the REDAuti of the CYTED. Coordinator of the EVA (Virtual Learning Spaces) Network at the Universidad Internacional de Andalucia (Spain). President of the Fundación Red Especial España (FREE). Scientific Director of the Multimedia Production Center for Interactive Television (CPMTI) and of the Center for Multimedia and Animation Innovation (CIMA) / Doctor en Ciencias por la Universidad de Córdoba [UCO], España. Profesor de Ingeniaría de Sistemas del Departamento de Informática de la UCO, experto en sistemas multimedia, interacción persona ordenador, usabilidad y accesibilidad Web, y sistemas interactivos. Director del Centro de Experimentación y Producción de Contenidos Digitales de la UCO (Red.es) y la CRUE (CITEC). Director del grupo de Investigación EATCO (Enseñanza y Aprendizaje por Tecnologías de la Comunicación). Director científico y creador de los productos, iFreeTablet, iFreeTV, iFreeSIN, iFreemovil, Siesta, SiestaTV, SiestaCare, SiestaDomo, Wikicursos y Tu-Learning. Responsable de Wikicursos de la REDAuti de la CYTED. Coordinador de la Red EVA (Espacios Virtuales de Aprendizaje) de la Universidad Internacional de Andalucía (UNIA). Presidente de la Fundación Red Especial España (FREE). Director Científico del Centro de Producción Multimedia para la Televisión Interactiva (CPMTI) y del Centro de Innovación Multimedia y Animación (CIMA).

Javier Ramos López Rector at the Universidad Rey Juan Carlos de Madrid [URJC], Spain. Doctor of Telecommunications Engineering from the Universidad Politécnica de Madrid (Spain). Former postdoctoral researcher at Universidad de Purdue (West Lafayette, IN). Ericsson Award for the best doctoral thesis awarded by the Official College of Telecommunications Engineers. Professor in the area of Signal Theory and Communications at the Universidad Carlos III de Madrid (1999-2003). Professor of Signal Theory and Communications at the URJC (2011). Director of the Higher Technical School of Telecommunications Engineering of the URJC (2005-2017). Fellowships at the Universidad de Minnesota (Minneapolis-MN, 2010) and at the Massachusetts Institute of Technology - MIT (Cambridge-MA, 2013). He has four research six-year terms and four five-year teaching periods. His areas of research are signal processing and information and its application to wireless communications and the processing of information on health problems (Big Data \& eHealth) / Rector de la Universidad Rey Juan Carlos de Madrid [URJC], España. Doctor Ingeniero de Telecomunicaciones por la Universidad Politécnica de Madrid. Ex investigador posdoctoral en la Universidad de Purdue (West Lafayette, IN). Premio Ericsson a la mejor tesis doctoral otorgado por el Colegio Oficial de Ingenieros de Telecomunicación. Profesor Titular en el área de Teoría de la Señal y Comunicaciones en la Universidad Carlos III de Madrid (1999-2003). Catedrático de Teoría de la Señal y Comunicaciones en la URJC (2011). Director de la Escuela Técnica Superior de Ingeniería de Telecomunicación de la URJC (2005-2017). Fellowships en la Universidad de Minnesota (Minneapolis-MN, 2010) y en el Massachusetts Institute of Technology (Cambridge-MA, 2013). Tiene cuatro sexenios de investigación y cuatro quinquenios docentes. Sus ámbitos de investigación son el procesado de señal e información y su aplicación a las comunicaciones inalámbricas y el procesado de información en problemas de salud (Big Data \& eHealth). 